\title{
As rochas básicas intrusivas das suítes Rio Branco e Salto do Céu, na região de Rio Branco (MT) sudoeste do Cráton Amazônico
}

\author{
Larissa Marques Barbosa de Araújo ${ }^{1}$, Antonio Misson Godoy ${ }^{2}$ \& Antenor Zanardo ${ }^{2}$
}

\begin{abstract}
Resumo O magmatismo básico encontra-se localizado na porção sudoeste do Cráton Amazônico (MT) inseridos no Domínio Tectônico Cachoeirinha e redefinido em dois eventos básicos independentes. Os diques máficos Mesoproterozóicos denominados de Suíte Básica Intrusiva Rio Branco constituem nas rochas plutônicas básicas/ intermediárias do Batólito Rapakivi Rio Branco e são compostas por microgabros a quartzo micrograbros e microdioritos a quartzo microdioritos, apresentando a sua distribuição descontínua e localizada principalmente na borda das rochas dominantes ácidas/intermediárias do batólito. As soleiras e diques mafícos Neoproterozóicos $( \pm$ $808 \mathrm{Ma}$ ), são agrupados sob a designação Suíte Básica Intrusiva Salto do Céu e são constituídos por diabásios e microgabros associados aos estratos do Grupo Aguapeí. O magmatismo Rio Branco é constituído a partir de dois magmas distintos de composição básica e ácida e representa um evento magmático de transição entre os tipos I e A, pós-orogênico a anorogênico e representando intrusões tardias no ciclo magmático, relacionados ao final do evento colisional da Orogenia Cachoeirinha. A Suíte Básica Intrusiva Rio Branco é constituída por basaltos alcalinos gerados em ambiente intraplaca. O magmatismo da Suíte Básica Intrusiva Salto do Céu apresenta-se distribuído no campo dos basaltos alcalinos e formado em ambiente intraplaca caracterizando um evento extensional, provavelmente relacionado aos mecanismos de colapso orogênico na evolução do cinturão Orogênico Sunsás-Aguapeí.
\end{abstract}

Palavras-chave: Cráton Amazônico, rochas básicas, Suíte Básica Intrusiva Salto do Céu, Suíte Básica Intrusiva Rio Branco.

\begin{abstract}
The intrusive basic rocks in the Rio Branco and Salto do Céu suites, Rio Branco (MT) region, southwestern of Amazonian Craton, Brazil. The basic magmatism is located in the southwestern portion of the Amazonian Craton (MT) belonging to the Cachoeirinha Tectonic Domain and redefined into two independent basic events. Mesoproterozoic mafic dikes named Rio Branco Intrusive Basic Suite are constituted by microgabbros to quartz microgabbros and microdiorites to quartz microdiorites, showing discontinuous distributions and localized mostly on the border of the acid to intermediate rocks of the batholiths. Neoproterozoic mafic sills and dikes ( $\pm 808 \mathrm{Ma}$ ) are grouped into the Salto do Céu Basic Suite and constituted by diabase and microgabbros associated to the Aguapei Group strata. Rio Branco magmatism is constituted from two distinct magmas of basic and acid composition and represents a post-orogenic to anorogenic magmatic event of transition between I and A types and environment representing late intrusions in the magmatic cicle, related to the end of the collisional event of Cachoeirinha Orogeny. The Rio Branco Intrusive Basic Suite is of alkaline basalts generated in an intraplate. The Salto do Céu Intrusive Basic Suite magmatism distributes along the field of alkaline basalts and formed into intraplate environment and characterizes an extensional event probably related to mechanisms of orogenic collapse in the Sunsás-Aguapei Orogenic Belt.
\end{abstract}

Keywords: Amazonian Craton, basic rocks, Salto do Céu Basic Intrusive Suite, Rio Branco Basic Intrusive Suite.

INTRODUÇÃO Na região sudoeste do Cráton Amazônico nas proximidades das cidades de Rio Branco e Salto do Céu no estado de Mato Grosso ocorrem em áreas marginais ao Batólito Rapakivi Rio Branco às rochas básicas, atualmente distintas nos diques máficos Mesoproterozóicos da Suíte Básica Intrusiva Rio Branco e as soleiras máficas Neoproterozóicas da Suíte Básica Intrusiva Salto do Céu. Caracterizam dois importantes registros geocronológicos, respectivamente, o da Província Geocronológica Rondoniana e o do Cinturão Sunsás/ Aguapeí segundo Tassinari \& Macambira (1999).

A área é constituída pelas rochas do Batólito Ra- pakivi Rio Branco individualizado nas unidades plutônicas ácida/intermediária e básica/intermediária e pelas rochas da unidade hipoabissal básica Salto do Céu (Araújo 2008), além das rochas Grupo Aguapeí. Estas rochas fazem parte do Domínio Tectônico Cachoeirinha que é constituído por um conjunto de segmentos crustais $\mathrm{Pa}$ leo-mesoproterozóicos, parcialmente reativados durante a Orogenia Sunsás, no Neoproterozóico (Ruiz 2005).

As ocorrências das unidades ígneas básicas e ácidas da região de Rio Branco e Salto do Céu (MT) foram inicialmente reportados por Oliva (1979), e denominadas de Complexo Serra de Rio Branco. 
Barros et al. (1982) denominam esta unidade com Grupo Rio Branco constituído por um conjunto plutôno-vulcânico bimodal, caracterizado por diabásio e gabros, na base e riodacitos, andesitos e dacitos, no topo. Leite et al. (1985), aplicam o termo Suíte Intrusiva Rio Branco, para englobar as rochas hipoabissais máficas e félsicas da Serra de Rio Branco, dividindo-a em duas unidades ígneas: a basal, unidade meso-melanocrática, composta por olivina gabros, gabros e quartzo dioritos, que transicionam para a unidade leucocrática, formada por quartzo monzonitos e sienitos.

Quanto ao caráter genético, esses autores preconizaram um modelo de evolução pela diferenciação de um magma basáltico toleítico em um lapólito, resultando em um complexo estratiforme diferenciado, interpretando essas ocorrências de rochas básicas como exposições da unidade meso-melanocrática da Suíte Intrusiva Básica Rio Branco, expostas em janelas erosivas da Formação Vale da Promissão do Grupo Aguapeí.

Geraldes (2000) e Geraldes et al. (2004), reavaliam o magmatismo bimodal da suíte, interpretando-o como uma interação de magmas máficos e félsicos conduzido por processos de commingling e mixing, descartando o modelo estratiforme, por diferenciação in situ.

Com relação à gênese do magmatismo básico e ácido Rio Branco, Araújo (2008) defende o aspecto bimodal, mas, sugere, a sua formação a partir de dois magmas, um de natureza básico gerado por derivação mantélica e o outro, de composição ácido/intermediário formado por processos de fusão de rochas da crosta inferior.

Araújo-Ruiz et al. (2005, 2007a,b) e Araújo (2008) com base nos dados de mapeamento geológico na escala 1:100.000 do Batólito Rapakivi Rio Branco e, a partir da caracterização petrográfica, geoquímica e geocronológica discriminaram para a área as suítes ácida/intermediária e básica/intermediária Rio Branco.

A suíte ácida/intermediária Rio Branco é constituída por granitos porfiríticos rapakivi, granofíricos, isotrópicos, de cor vermelha, com a presença de fenocristais de feldspato potássico, de até $4 \mathrm{~cm}$, envoltos em matriz fina a média, constituído por três fácies petrográficas: monzogranitos equi-inequigranulares a pegmatóides, leuco-monzogranitos vermelhos rapakivis e monzogranitos a quartzo monzonitos vermelhos escuros rapakivis.

As rochas básicas/intermediárias plutônicas, designadas de Suíte Básica Intrusiva Rio Branco são constituídas por gabros a quartzo grabros e dioritos a quartzo dioritos e apresentam diferencialmente dos demais autores, uma distribuição localizada e descontínua, restrita principalmente à borda da intrusão ácida ou na forma de pequenas ocorrências no interior do Batólito Rapakivi Rio Branco.

Os litotipos hipoabissais formando diques e sills são constituídos por diabásios e microgabros e apresentam ocorrência ampla e encontram-se dominantemente alojados concordantes aos estratos do Grupo Aguapeí. A esse conjunto de soleiras máficas, exposto nas regiões de Salto do Céu, Vila Progresso e Rio Branco, foi sugerido o termo Suíte Básica Intrusiva Salto do Céu Araújo-Ruiz et al. (2005, 2007a,b).
GEOLOGIA REGIONAL A evolução Proterozóica do Cráton Amazônico segundo Tassinari \& Macambira (1999), é caracterizada pela acresção de cinturões móveis que se anexaram ao núcleo arqueano do protocráton Amazônico, possibilitando a identificação do Cinturão Maroni-Itacaiunas (2,2 a 2,0 Ga), Cinturão Venturi-Tapajós (2,1 e 1,9 Ga), Província Rio NegroJuruena (1,7 e 1,55 Ga), Província Rondoniana (1,5 e $1,3 \mathrm{Ga})$ e o Cinturão Sunsás/Aguapeí (1,0 e 0,9 Ga).

A proposta de compartimentação em Domínios Tectônicos apresentada por Ruiz (2005) e Ruiz et al. (2005) e utilizada neste trabalho, subdivide a porção sudoeste do Cráton Amazônico em cinco domínios tectônicos distintos denominados de Domínio Cachoeirinha, Jauru, Rio Alegre, Santa Bárbara e Paragua. Dentro deste contexto, a região estudada estaria inserida no Domínio Cachoeirinha, que corresponde ao setor oriental dos terrenos pré-cambrianos do sudoeste do Cráton Amazônico em Mato Grosso, constituído pelas seguintes unidades litoestratigráficas: Complexos Metavulcano-sedimentares Cabaçal e Quatro Meninas, Suíte Intrusiva Máficaultramáfica, Unidades Ortognáissicas, Tonalito Cabaçal, Suíte Intrusiva Santa Cruz, Suíte Intrusiva Alvorada e pelas unidades, o Batólito Rapakivi Rio Branco, o Grupo Aguapeí e na Suíte Intrusiva Básica Salto do Céu.

Araújo-Ruiz et al. (2007a) definem o magmatismo do Batólito Rapakivi Rio Branco constituído pelas suítes ácidas/intermediárias, de caráter dominante e uma básica/intermediária de ocorrência restrita e localizada, e portanto não apresentando a mesma configuração areal inicial de Barros et al. (1982) e adotada por Leite et al. (1985), Geraldes (2000) e Geraldes et al. (2004).

Quanto ao posicionamento estratigráfico, Leite et al. (1985), Geraldes (2000) e Geraldes et al. (2004), situam as rochas básicas e ácidas do batólito como embasamento do Grupo Aguapeí, enquanto Araújo-Ruiz et al. $(2005,2007 \mathrm{a})$ reforçam a posição inicial de Barros et al. (1982) de um evento magmático intrusivo nas unidades do Grupo Aguapeí, a partir da constatação por Ruiz (2005), da ocorrência de xenólitos de metargilitos da Formação Vale da Promissão em rochas do batólito e indícios de metamorfismo de contato de discreta expressão em metapelitos da mesma formação, também apoiadas nas idades $\mathrm{Rb} / \mathrm{Sr}$ reportados por Barros et al. (1982) de $1130 \pm 72 \mathrm{Ma}$ e Ruiz (1992) $1126 \pm 39 \mathrm{Ma}$.

Os dados U-Pb obtidos por Geraldes (2000) apresentam idades de 1,46 e 1,42 Ga para as rochas básicas e félsicas, respectivamente e as idades modelo $\mathrm{T}_{\mathrm{DM}}$ apresentadas indicam que o protólito das rochas básicas foi formado entre 1,86 e 1,82 Ga e para as félsicas entre 1,80 e 1,73 Ga. Geraldes (2000) faz uma relação entre as idades obtidas em comparação com os de Barros et al. (1982) e Ruiz (1992) e sugere que a diferença de 300 Ma entre ambas as idades representaria provavelmente o resultado da atividade hidrotermal que afetou as rochas da Suíte Rio Branco, já que estas rochas não se apresentam afetadas pelo metamorfismo regional.

Araújo (2008) em datação U-Pb de rochas da suíte ácida/intermediária do Batólito Rio Branco obteve idade $1406 \pm 0.6 \mathrm{Ma}$, que é interpretada como sendo 
a idade de cristalização do magma félsico e condizentes com as idades obtidas por Geraldes (2000).

A partir das datações em zircões detríticos obtidos do Grupo Aguapeí de 1230 Ma com idades de deposição máxima por Santos et al. (2000) e de zircões detríticos obtidas da amostra da Serra Ricardo Franco de $1260 \mathrm{Ma}$ por Vargas-Matos et al. (2007) definiram esta idade mais jovem como a idade máxima de deposição do grupo por correlação entre as unidades do Grupo Aguapeí. Araújo (2008) revê posicionamento estratigráfico assumido inicialmente, passando, portanto as unidades metassedimentares do Grupo Aguapeí como pós-magmática.
A Bacia Sedimentar Aguapeí, segundo Saes (1999), teria evoluído em um regime tectônico extensional, responsável pela formação de estruturas do tipo riftes continentais orientados (Aulacógeno Aguapeí) e que controlaram a natureza da sedimentação siliciclástica.

GEOLOGIA LOCAL Na área foram reconhecidas as seguintes unidades litoestratigráficas, o Batólito Rapakivi Rio Branco, a Suíte Intrusiva Salto do Céu e o Grupo Aguapeí encobertos parcialmente pelos sedimentos da Bacia do Pantanal. A seção geológica esquemática situada a norte da cidade de Rio Branco (Fig. 1) ilustra as

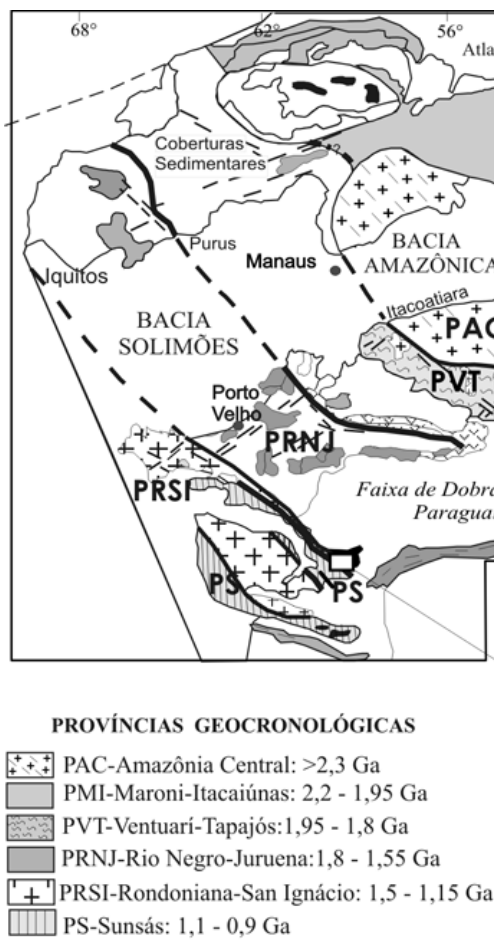

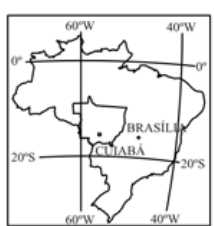
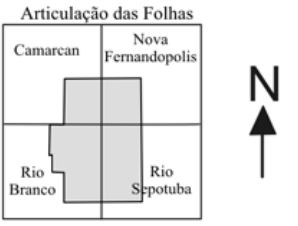

Unidades Litológicas

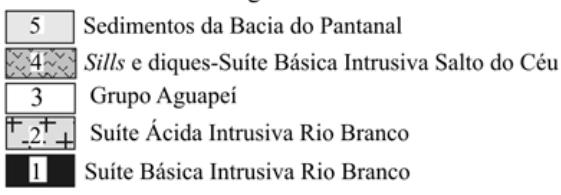

CONVENÇÕES

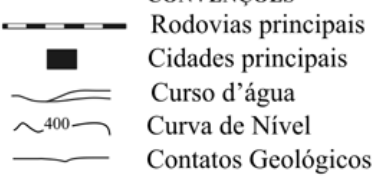

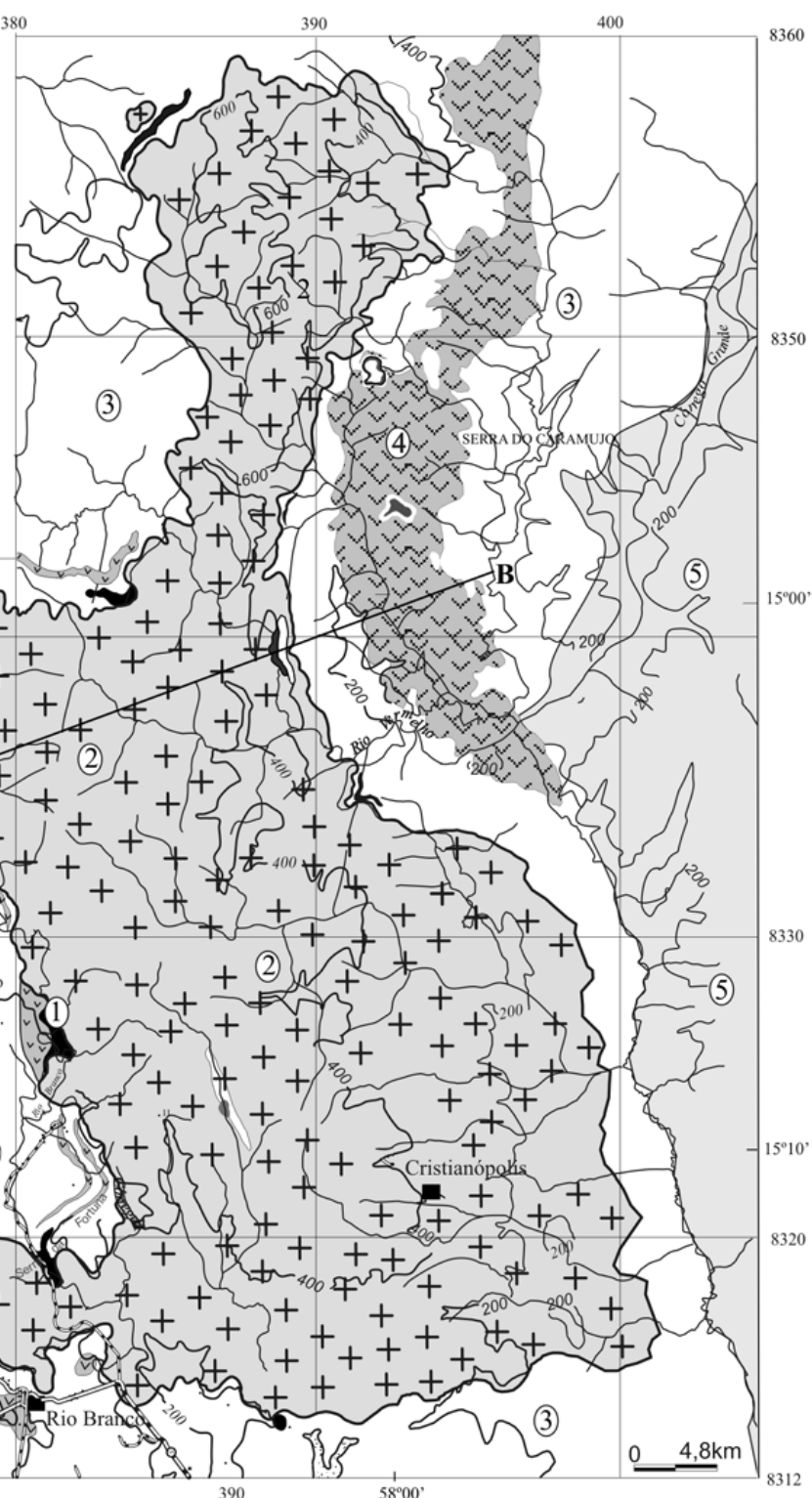

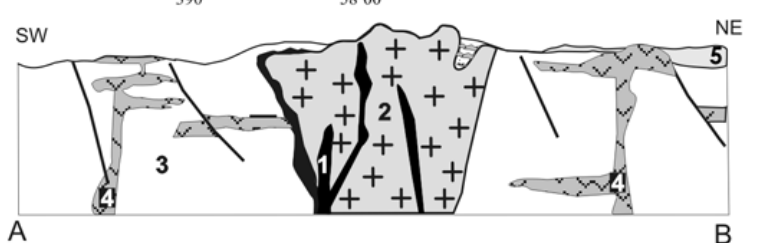

Figura 1 - Mapa geológico e perfil esquemático (SW-NE) do Batólito Rapakivi Rio Branco e suas encaixantes e mapa de localização da área dentro das províncias geocronológicas de Tassinari \& Macambira (1999). 
relações estratigráficas entre as unidades mapeadas.

O Batólito Rapakivi Rio Branco é constituído pelas suítes ácida/intermediária e básica/intermediária Rio Branco que se encontram encobertas parcialmente a oeste pelos metassedimentos do Grupo Aguapeí e a leste pelos sedimentos quaternários da Formação Pantanal.

A Suíte Ácida Intrusiva Rio Branco (AraújoRuiz et al. 2007a) ocorre em uma faixa de direção norte-sul, com aproximadamente $75 \mathrm{~km}$ de comprimento e $30 \mathrm{~km}$ de largura. Abrange uma área aflorante de cerca de $1.500 \mathrm{~km}^{2}$, ocupando $95 \%$ da área do batólito, destacando afloramentos na forma de blocos e matacões. O batólito compreende uma fácies básica e três fácies ácidas/intermediárias representadas principalmente pelos leuco-monzogranitos vermelhos rapakivis (Fig. 2A) ao lado de quantidades menores de monzogranitos a quartzo monzonitos vermelhos escuros rapakivis e raros quartzo monzodioritos que ocorrem na forma de enclaves e as fácies tardias de monzogranitos equi-inequigranulares a pegmatóides. Estas fácies são frequentemente porfiríticas com raros a abundantes fenocristais manteados, constituindo texturas rapakivis e raramente anti-rapakivis.
A Suíte Básica Intrusiva Rio Branco é identificada principalmente na borda oeste da intrusão ácida, não sendo verificado o caráter estratiforme diferenciado, mas sim, um comportamento desta unidade distribuída descontinuamente na borda do batólito, sendo caracterizada principalmente por diques que ocorrem na borda do batólito de direção aproximadamente $\mathrm{N}-\mathrm{S}$, principalmente entre as localidades de Rio Branco e Salto do Céu.

Os diques encontram-se intrusivos entre o contato das rochas encaixantes epimetamórficas do Grupo Aguapeí e o conjunto ácido dominante do batólito, sendo caracterizados petrograficamente por litotipos mesocráticos, de cor cinza a negra, equigranulares de granulação fina a média, dominante e às vezes porfirítica, exibindo estrutura maciça e composta por microgabros a diabásios, monzogabros e quartzo monzonitos a quartzo dioritos (Fig. 2B). Ocorrem em afloramentos de cortes de estrada nos contrafortes do batólito ou em matacões principalmente nestas áreas. Ocorrências no interior do corpo ácido são restritas na forma de pequenos corpos distintos ou na forma de diques máficos sinintrusivos associados à fácies principal (Fig. 2E).
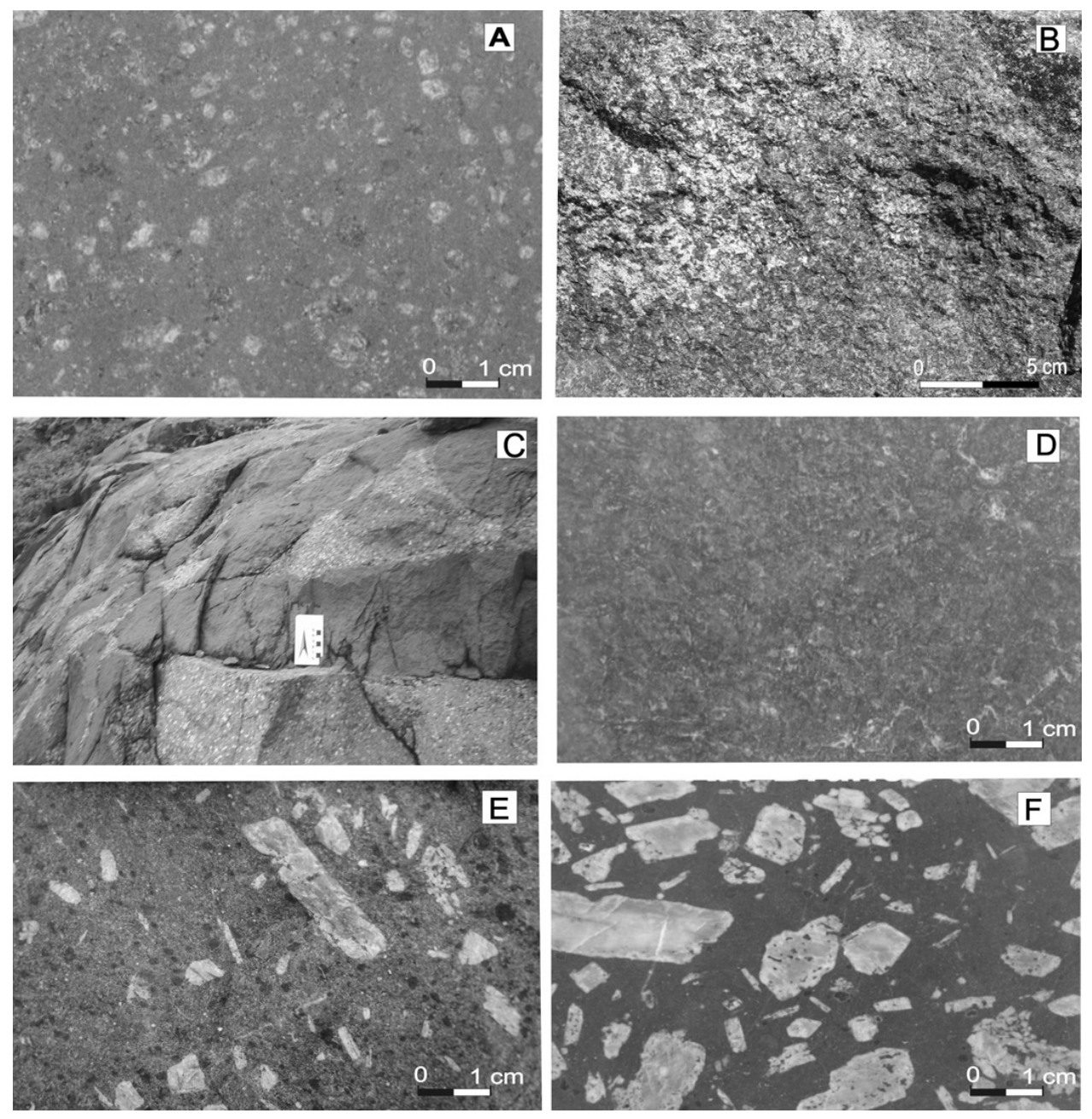

Figura 2 - Fotografias macroscópicas das rochas do Batólito Rapakivi Rio Branco. A) leuco-monzogranito vermelho rapakivi, B) micrograbos, C) diques máficos sin-intrusivos no leuco-monzogranito e das rochas da Suite Básica Intrusiva Salto do Céu, D) diabásios equigranulares e E, F) diabásios porfiríticos. 
A evolução magmática do batólito é representada concomitantemente por uma fase inicial, definida inicialmente pelas intrusões de rochas básicas laterais ao batólito, acompanhado por rochas de composição intermediária, preservada por micro-enclaves de quartzo monzodioritos e pelas fácies de monzogranitos a quartzo monzonitos vermelho escuro rapakivi. A fase principal é caracterizada pelas grandes massas de leucomonzogranitos rapakivis que constituem a parte central do batólito e a fase final é constituída pelas fácies equigranulares e aplíticas que cortam todas as anteriores, às vezes, com feições pegmatíticas.

Todo o conjunto plutônico não exibe evidências de deformação dúctil e metamorfismo, sendo apenas recortado por falhas normais de direção NNW e NEE que afetam também suas encaixantes.

A Suíte Básica Intrusiva Salto do Céu é constituída por dezenas de soleiras máficas composta por diabásios e microgabros, com espessura variando entre 1 a $5 \mathrm{~m}$, paralelas ao acamamento dos metapelitos e metapsamitos da Formação Vale da Promissão.

As variedades texturais equigranulares das rochas dos sills encontram-se representadas na (Fig. 2D) e as porfiríticas apresentam com certa frequência em dois tipos principais. As porfiríticas de matriz fina com fenocristais de plagioclásio subédricos com dimensões inferiores a 1 $\mathrm{cm}$ e com porcentagens entre 5 a $15 \%$ de coloração branca a esverdeada quando epidotizados (Fig. 2E) e as porfiríticas de matriz fina com grandes fenocristais e uma distribuição bimodal, uma, com tamanhos de até $1 \mathrm{~cm}$ e a outra com dimensões de até $3 \mathrm{~cm}$, e menos frequentemente, podem ocorrer fenocristais de até $5 \mathrm{~cm}$ (Fig. 2F).

O Grupo Aguapeí é uma espessa cobertura siliciclástica dividida em três formações, compreendendo, da base ao topo, as formações Fortuna, Vale da Promissão e Morro Cristalina. A Formação Fortuna constituise por espessos pacotes de conglomerados oligomíticos e arenitos quartzosos, com intercalações em direção ao topo de metassiltitos e metargilitos, depositados em um ambiente de mares rasos e correntes de marés.

A Formação Vale da Promissão exibe um contato transicional interdigitado com a unidade sotoposta e compreende uma sequência dominada por metargilitos e metassiltitos e raros metarenitos depositados em um ambiente marinho profundo, sob ação de ondas de tempestades; uma espessa sequência fluvial encerra a deposição do grupo com o registro de areias de corrente da Formação Morro Cristalina.

Características petrográficas das rochas da Suíte Básica Intrusiva Rio Branco Esta suíte é composta por rochas mesocráticas, isotrópicas e formadas principalmente por minerais de plagioclásio, piroxênio (augita e secundariamente pigeonita) e anfibólio alterando-se para clorita, localmente restos de olivinas serpentinizadas, raro quartzo que ocorre em pequenos grãos intersticiais e como acessórios ocorrem opacos e apatita, além de produtos de alteração, epidoto e calcita. Os litotipos petrográficos dominantes encontram-se definidos na (Tab. 1).

O Gabro com Olivina constitui uma rocha de cor cinza escuro a claro, variando de granulação fina a média e da quantidade de máfico. Ao microscópio a textura é subofítica, com domínios ofíticos a intergranular, com granulação média na ordem de $0,7 \mathrm{~mm}$ e os maiores cristais de augita e de plagioclásio atingem cerca de $3,5 \mathrm{~mm}$ de comprimento. É constituída basicamente por $\pm 58 \%$ de plagioclásio, $\pm 20 \%$ de augita, $\pm 15 \%$ pseudomorfo de olivina, $\pm 5 \%$ de minerais opacos, $\pm 1 \%$ de anfibólio, $>1 \%$ de apatita e traços de biotita e titanita.

O plagioclásio constitui cristais ripiformes a tabulares, normalmente com comprimento inferior a 2 $\mathrm{mm}$, disposto caoticamente apresentando intensa alteração, em especial, as porções mais cálcicas que formam um zoneamento composicional. A alteração aparece sob a forma de manchas que chegam a dominar todo o núcleo do cristal. O produto de alteração dominante é constituído por sericita associada à clinozoisita, chegando a gerar texturas com aspecto micro a criptosimplectítico.

A augita ocorre como cristais maiores englobando outros minerais (olivina, plagioclásio e opacos), e também intersticialmente, exibe cor creme e localmente manchas de alteração, podendo representar uma mudança na composição.

Os pseudomorfos de olivina são anedrais a subedrais e compostos por filossilicatos verdes e actinolita. Entre os filossilicatos podem ser reconhecidas a clorita e/ou serpentina e um material de birrefringência mais alta que podem ser a biotita verde, illita ou minessotaíta. Os principais opacos ocorrem sob a forma anedral a euedral, tamanhos milimétricos a submilimétricos, dispersos por toda a lâmina.

Outro produto de alteração gerado nos pseudomorfos é a titanita microcristalina, que aparece formando minúsculos glóbulos. O anfibólio (actinolita) ocorre como acículas bordejando piroxênio, isoladas no interior dos pseudomorfos, formando ou não agregados fibrosos e raros cristais com dimensões maiores. A biotita ocorre na forma raros cristais de cor vermelha a marrom escura e a apatita constitui delgados cristais prismáticos a aciculares euédricos, com dimensões submilimétricas até cerca de $1 \mathrm{~mm}$.

O Gabro Porfiritico com quartzo apresenta textura porfirítica com fenocristais de até $5 \mathrm{~mm}$ de comprimento, com média pouco inferior a $1 \mathrm{~mm}$ e matriz fina, intragranular e inequigranular. Basicamente é constituído por $\pm 60 \%$ de plagioclásio, $\pm 15 \%$ de clinopiroxênio (augita/diopsídio), $\pm 15 \%$ de agregados de filossilicatos verdes, $\pm 6 \%$ de minerais opacos, $\pm 3 \%$ de quartzo, $\pm 1 \%$ de apatita e traços de titanita, biotita e de estilpnomelano.

O plagioclásio destaca-se na forma de cristais tabulares a ripiformes com geminação albita e Carlsbad, dispersos de forma a definir uma leve orientação de fluxo, apresentando comumente forte alteração por filossilicatos incolores (sericita), outras vezes com manchas de aspecto micro simplectíticos constituídas por minerais opacos. Esporadicamente aparecem microfraturas preenchidas por filossilicatos microcristalino verdes.

O clinopiroxênio (augita/diopsídio) ocorre sob a forma de cristais pequenos a médios, onde os menores dispõem-se entre as ripas de plagioclásio. Sua borda 
Tabela 1 - Síntese dos dados petrográficos da Suite Básica Intrusiva Rio Branco e Suite Básica Intrusiva Salto do Céu.

\begin{tabular}{|c|c|c|c|c|c|c|}
\hline \multirow[b]{2}{*}{ Amostra } & \multicolumn{4}{|c|}{ Suíte Básica Intrusiva Rio Branco } & \multicolumn{2}{|c|}{ Suíte Básica Intrusiva Salto do Céu } \\
\hline & $\begin{array}{l}\text { Gabro c/ } \\
\text { olivina }\end{array}$ & $\begin{array}{c}\text { Gabro c/ } \\
\text { quartzo }\end{array}$ & $\begin{array}{l}\text { Quartzo } \\
\text { monzonito }\end{array}$ & $\begin{array}{l}\text { Quartzo } \\
\text { diorito }\end{array}$ & $\begin{array}{c}\text { Diabásio/ } \\
\text { Monzodiabásio }\end{array}$ & $\begin{array}{c}\text { Diabásio c/ } \\
\text { quartzo }\end{array}$ \\
\hline \multicolumn{7}{|l|}{ M. Principais } \\
\hline Plagioclásio & 58 & 60 & 40 & 40 & 65 & 65 \\
\hline Augita & 20 & 15 & 3 & 8 & 15 & 15 \\
\hline Hiperstênio & & $?$ & $?$ & 1 & & $?$ \\
\hline Olivina & pseudomorfos & & & 1 & & \\
\hline Hornblenda & & & 15 & 15 & 10 & 2 \\
\hline Quartzo & & 3 & 13 & 7 & & \\
\hline Ortoclásio & & & 20 & 15 & & \\
\hline Biotita & presente & & & & & \\
\hline \multicolumn{7}{|l|}{ M. Acessórios } \\
\hline Apatita & 1 & 1 & 1 & 1 & 1 & 1 \\
\hline Titanita & traços & traços & & & & traços \\
\hline Opaco & 5 & 6 & 5 & 5 & 6 & 4 \\
\hline \multicolumn{7}{|l|}{ M. Secundários } \\
\hline Filossilicatos & 15 & 15 & 3 & 5 & $\operatorname{tr}$ & 10 \\
\hline Hornblenda & & presente & & & & \\
\hline Actinolita & 1 & presente & & traços & & \\
\hline Clorita & presente & & & & 2 & \\
\hline Serpentina & presente & & & & & \\
\hline Biotita & presente & traços & & traços & 1 & traços \\
\hline Estilpnomelano & & traços & & traços & & \\
\hline Sericita & & presente & & & & traços \\
\hline Epidoto & & & & & & traços \\
\hline
\end{tabular}

apresenta transformação para anfibólio (hornblenda e actinolita) de cor bege claro.

Os filossilicatos microcristalinos verdes ocorrem formando agregados com formas externas irregulares, tabulares, submilimétricas a milimétricas (raramente alcançam $2 \mathrm{~mm}$ de diâmetro ou comprimento). Apresentam pleocroísmo variando de verde a levemente verde claro, sugerindo tratar-se de mineral do grupo da clorita. Esporadicamente aparecem minúsculos cristais, sugerindo ser clorita oxidada ou biotita verde. Esses agregados mostram-se formados pela alteração de um mineral máfico, possivelmente piroxênio, porém as formas dos pseudomorfos não permitem definir qual foi o mineral original. Este agregado é formado por opacos, glóbulos de titanita microcristalina, opacos anedrais e anfibólio (actinolita) acicular, sugerindo tratar-se de piroxênio (provavelmente ortopiroxênio).

O anfibólio ocorre como raros restos de hornblenda marrom avermelhado e acículas de actinolita dispostas nas bordas dos cristais de augita e nos agregados de clorita. No interior do plagioclásio foi observado agregado, com forma subedral que aparenta ser da série cummingtonita/ grunerita sugerindo alteração de ortopiroxênio.

$\mathrm{O}$ quartzo ocorre intersticialmente sob a forma de cristais submilimétricos anedrais. Como minerais acessórios destacam-se a apatita e como mineral secundário o estilpnomelano na forma de filetes, constituídos por minúsculos cristais que cortam os agregados de clorita.

O Quartzo Monzonito Porfiritico apresenta ocorrência localizada e restrita ao contato com as rochas ácidas do batólito, constituindo tipos isotrópicos, de cor variando entre cinza a rosado e porfirítico. Observa-se uma textura porfirítica com matriz granofírica e granulação dos feno- cristais de até $8 \mathrm{~mm}$, constituída por $\pm 40 \%$ de plagioclásio, $\pm 20 \%$ de ortoclásio, $\pm 15 \%$ de anfibólio, $\pm 13 \%$ de quartzo, $\pm 5 \%$ de opacos, $\pm 3 \%$ de restos de clinopiroxênio, menos de $1 \%$ de apatita com a presença de minerais de alteração como os filossilicatos verdes em torno de $\pm 3 \%$.

Os fenocristais que se destacam são de plagioclásio que ocorrem sob a forma de cristais tabulares a ripiformes curvos, normalmente menores que $2,5 \mathrm{~mm}$, fortemente alterados para filossilicatos incolor (sericita). O ortoclásio ocorre na matriz intercrescido com o quartzo gerando textura granofírica e formando fenocristais que podem conter filmes de albita e coroa de albita (textura orbicular/rapakivi).

O anfibólio é representado dominantemente por hornblenda verde, comum a hastingsita e secundariamente por actinolita. Em alguns cristais observam-se restos de clinopiroxênio especialmente no interior dos maiores cristais de anfibólio.

Todos os restos de piroxênio são de clinopiroxênio, às vezes com geminação e desmisturação basal, todavia aparecem agregados de filossilicatos verdes e manchas ricas em filossilicatos microcristalinos de cor marrom a verde no interior de cristais de anfibólio, que sugerem a presença de outro mineral máfico, além do clinopiroxênio, possivelmente hiperstênio. A biotita aparece na forma de placas com franja simplectítica, normalmente associada aos filossilicatos verdes e opacos.

O quartzo é anedral, intercresce com o ortoclásio e apresenta granulação fina constituindo a matriz. Os opacos formam cristais anedrais a subedrais, às vezes esqueletais com diâmetro de até $1 \mathrm{~mm}$. Alterações comuns são representadas pelos microcristais de filossilicato verde que ocorrem intersticialmente e formam 
pequenas manchas (pseudomorfos de mineral máfico) constituído por clorita e biotita.

O Quartzo Diorito Fino caracteriza-se pela textura granular hipidiomórfica, granulação fina, inequigranulares, onde os maiores cristais raramente alcançam $3 \mathrm{~mm}$ e a média é na ordem de $0,5 \mathrm{~mm}$. É constituído basicamente por $\pm 40 \%$ de plagioclásio, $\pm 15 \%$ hornblenda, $\pm 15 \%$ ortoclásio, $\pm 7 \%$ quartzo e $\pm 8 \%$ augita, $\pm 1 \%$ hiperstênio, $\pm 1 \%$ biotita, $\pm 5 \%$ opacos e como acessórios a $\pm 1 \%$ apatita, traço de estilpnomelano e $\pm 5 \%$ filossilicatos verdes de geração tardia.

O plagioclásio (andesina a labradorita) ocorre sob a forma de cristais tabulares turvos levemente zonados. Estão parcialmente alterados para filossilicatos finos incolores (sericita), sendo que os mais alterados exibem pontuações de hematita, frequentemente os plagioclásios apresentam formas de corrosão em contatos com os feldspatos alcalinos tardios.

O feldspato potássico (ortoclásio) ocorre intersticialmente intercrescido com quartzo, gerando textura granofírica e chega a formar alguns cristais maiores, tendendo a fenocristal. Possui minúsculas pontuações de hematita distribuídas heterogeneamente formando difusas manchas.

O anfibólio é representado por hornblenda, que exibe variação na cor refletindo mudança composicional decorrente da diminuição de temperatura durante a formação dessa fase cristalina. Os cristais mais antigos caracterizam-se para hornblenda e as fases finais aparecem sob a forma de pequenas fibras de actinolita.

O quartzo é anedral, intersticial, intercrescidos ou moldando cristais euedrais a subedrais de ortoclásio na matriz sendo estes submilimétricos.

Ocorrem duas gerações de biotita distintas, ambas são submilimétricas, anedrais a subedrais. A mais antiga de cor marrom avermelhado a alaranjado e outra de cor esverdeada, típica de transformação do piroxênio.

Os piroxênios ocorrem como cristais anedrais corroídos, no interior dos anfibólios e são representados por dois tipos, um de cor bege, fracamente pleocróico, sem exsolução e outro com exsolução basal de opaco. $O$ hiperstênio ocorre como restos irregulares no interior do clinopiroxênio, do anfibólio ou de agregados de filossilicatos microcristalinos. Estes agregados formam manchas (pseudomorfos), anedrais, de cor verde, constituídos por uma associação de microcristais de biotita/illita de cor verde e clorita, localmente aparecendo microcristais marrons avermelhados fibrosos a aciculares de estilpnomelano.

Os opacos encontram-se distribuídos sob a forma de cristais anedrais a subedrais, frequentemente esqueletiformes dispersos na rocha. A apatita e o zircão ocorrem sob a forma de minúsculos cristais euedrais a subedrais dispersos na lâmina ou em outros minerais como inclusões.

Características petrográficas das rochas da Suíte Básica Intrusiva Salto do Céu Os sills característicos da Suíte Básica Intrusiva Salto do Céu variam texturalmente de microgabros a microdiabásios, mesocráticas, maciços, cinza escuros a negros, equigranulares de granulação fina a média, e localmente apresentando expressivas texturas porfiríticas. No geral o plagioclásio (labradorita- andesina) ocorre comumente na matriz, como cristais euédricos a subeuédricos, tabulares, e menos frequentemente, como fenocristais de até $5 \mathrm{~cm}$ de comprimento.

A matriz é composta por plagioclásio, piroxênio, hornblenda, biotita, feldspato potássico e quartzo. A textura cumulática e ofítica é comum e os minerais acessórios são representados pelo zircão, titanita, magnetita, ilmenita e pirita. Os litotipos petrográficos dominantes encontram-se definidos na (Tab. 1).

O Diabásio a Monzodiabásio microporfirítico apresenta textura microporfirítica, localmente apresentando domínios de textura granofírica, constituído por fenocristais que alcançam até $3 \mathrm{~mm}$ de comprimento, com média pouco inferior a $0,8 \mathrm{~mm}$ e matriz fina, intragranular, inequigranular. Basicamente é constituído por $\pm 65 \%$ de plagioclásio, $\pm 15 \%$ de clinopiroxênio (augita/ diopsídio), $\pm 10 \%$ de hornblenda, $\pm 6 \%$ de minerais opacos, $\pm 2 \%$ de clorita, $\pm 1 \%$ de apatita, $\pm 1 \%$ de biotita.

O plagioclásio representa o principal fenocristal deste litotipo, destacam-se na forma de cristais tabulares a ripiformes com geminação albita e Carlsbad, comumente límpidos, constituindo junto ao piroxênio a textura subofítica. Quando alterado apresenta formação de sericita.

O clinopiroxênio (augita/diopsídio) aparece sob forma de cristais pequenos a médios, distribuído em geral entre as ripas de plagioclásio. No geral ocorre alteração na borda dos cristais maiores para anfibólio (hornblenda) geralmente juntos e associados a estes cristais, observam-se agregados irregulares constituídos por opacos irregulares e esqueletais, biotita com aspecto fibroso e clorita.

O anfibólio (hornblenda) em geral aparece sob a forma de cristais irregulares, anedrais, de pleocroísmo verde claro a verde escuro, junto a outros minerais de alteração como os agregados de clorita. Como minerais acessórios identificam-se apatitas subéudricas e como mineral de alteração ocorrem clorita, sericita e opacos.

O Diabásio Porfiritico com quartzo aflora a norte do batólito; ao microscópio apresenta textura porfirítica com matriz fina, intergranular a subofítica. Os fenocristais de plagioclásio atingem cerca de $7 \mathrm{~mm}$ de comprimento e a granulação média da matriz é na ordem de $1 \mathrm{~mm}$. Constituída basicamente por $\pm 65 \%$ de plagioclásio, $\pm 15 \%$ de augita, $\pm 10 \%$ de filossilicato, $\pm 4 \%$ de minerais opacos, $\pm 2 \%$ de anfibólio, $\pm 1 \%$ de apatita e traços de biotita e titanita.

O plagioclásio está parcialmente alterado não possibilitando a determinação de sua composição, em seu núcleo aparecem pontuações e manchas marrons constituídas por sericita e formação de clinozoisita. Também ocorrem manchas e filetes de filossilicato microcristalino de cor verde (clorita) e agregado fibro radiado que aparenta ser anfibólio do grupo da cummingtonita/grunerita, sugerindo a presença de hiperstênio.

A augita ocorre sob a forma de cristais anedrais a subedrais intersticiais e cristais maiores englobando plagioclásios formando a textura subofítica a ofítica. Nas bordas de alguns cristais aparecem coroas de anfibólio de coloração marrom escuro, verde forte e verde claro.

O anfibólio aparece como produto de altera- 
ção do clinopiroxênio e é representado por hornblenda marrom, hornblenda verde e actinolita. A actinolita é fibrosa e ocorre formando barbas ou franjas no piroxênio e intercrescida com filossilicato nos pseudomorfos, chegando a alguns casos a ser o principal constituinte do pseudomorfo.

Os filossilicatos microcristalinos verdes ocorrem na forma de manchas irregulares a subtabulares, intersticiais ou não, às vezes, englobando o plagioclásio, com dimensões submilimétricas alcançando até 1 $\mathrm{mm}$. Nas bordas frequentemente aparece uma película de índice de refração mais alto que aparenta ser de anfibólio (actinolita microcristalina e fibrosa). Esses filossilicatos correspondem a pseudomorfos, possivelmente de ortopiroxênio, todavia com formas que não permitem excluir a possibilidade da presença de olivina.

Os minerais opacos constituem cristais ripiformes, esqueléticos, irregulares a subedrais, normalmente submilimétricos e dispersos. Geralmente, aparecem capeados por titanita e/ou óxido de titânio microcristalino. O quartzo aparece como pequenos cristais, submilimétricos, intersticiais distribuídos na matriz. Acessórios como a apatita ocorre na forma acicular euedral, titanita aparece na forma de coroa nos cristais de opacos e como glóbulos e agregados irregulares no interior dos pseudomorfos, raros cristais de biotitas aparecem na borda dos piroxênios e dos opacos.

LITOGEOQUÍMICA As análises geoquímicas (Tab. 2) das amostras da Suíte Básica Intrusiva Rio Branco (SBIRB) e as das amostras da Suíte Básica Intrusiva Salto do Céu (SBISC) foram realizadas no LABOGEO-IGCE/UNESP-Rio Claro utilizando-se Fluorescência de Raios X para os elementos maiores (concentração em \%), através de pastilha fundida em meio borato e para os elementos traços (concentração em ppm), através de pastilha prensada, e para os elementos de terras raras, ICP-AES, segundo os padrões

Tabela 2 - Tabela de geoquímica das amostras da Suite Básica Intrusiva Rio Branco (ロ), amostras: 1-gabro com olivina; 2, 3-gabro porfirítico com quartzo; 4-quartzo monzonito porfiritico;5, 6-quartzo diorito fino e das amostras da Suite Básica Intrusiva Salto do Céu (⿶), amostras: 7, 8, 9, 10-diabásio a monzodiabásio microporfirítico e 11, 12-diabásio porfirítico com quartzo.

\begin{tabular}{|c|c|c|c|c|c|c|c|c|c|c|c|c|}
\hline \multirow[b]{2}{*}{ Amostras } & \multicolumn{6}{|c|}{ Suíte Básica Intrusiva Rio Branco (ם) } & \multicolumn{6}{|c|}{ Suíte Básica Intrusiva Salto do Céu $(\boldsymbol{\Delta})$} \\
\hline & 1 & 2 & 3 & 4 & 5 & 6 & 7 & 8 & 9 & 10 & 11 & 12 \\
\hline $\mathrm{SiO}_{2}$ & 45,07 & 47,36 & 50,68 & 51,54 & 52,66 & 53,34 & 44,47 & 44,66 & 44,81 & 45,05 & 46,15 & 47,82 \\
\hline $\mathrm{TiO}_{2}$ & 2,22 & 2,87 & 2,98 & 2,07 & 2,87 & 2,7 & 4,03 & 3,37 & 1,97 & 2,34 & 3,88 & 1,78 \\
\hline $\mathrm{Al}_{2} \mathrm{O}_{3}$ & 16,37 & 17,98 & 16,04 & 14,34 & 12,37 & 13,48 & 14,39 & 15,65 & 17,22 & 16,13 & 13,95 & 17,33 \\
\hline $\mathrm{Fe}_{2} \mathrm{O}_{3}$ & 13,17 & 11,6 & 13,15 & 13 & 14,76 & 14,08 & 16,71 & 15,23 & 13,59 & 15,25 & 15,35 & 11,99 \\
\hline $\mathrm{MnO}$ & 0,14 & 0,16 & 0,2 & 0,21 & 0,25 & 0,17 & 0,19 & 0,15 & 0,2 & 0,22 & 0,22 & 0,2 \\
\hline $\mathrm{MgO}$ & 6,23 & 3,87 & 3,46 & 1,53 & 3,11 & 3,15 & 4,66 & 5,4 & 7,1 & 6,66 & 4,98 & 6,44 \\
\hline $\mathrm{CaO}$ & 9,5 & 6,37 & 5,66 & 5,28 & 5,22 & 6,04 & 8,5 & 6,33 & 8,04 & 8,84 & 5,65 & 8,94 \\
\hline $\mathrm{Na}_{2} \mathrm{O}$ & 3,46 & 3,37 & 3,52 & 4,73 & 3,53 & 3,35 & 2,96 & 3,59 & 2,48 & 2,51 & 2,94 & 2,64 \\
\hline $\mathrm{K}_{2} \mathrm{O}$ & 0,38 & 3,03 & 1,63 & 4,15 & 2,61 & 2,64 & 0,74 & 1,97 & 1,5 & 0,6 & 2,87 & 0,7 \\
\hline $\mathrm{P}_{2} \mathrm{O}_{5}$ & 0,44 & 0,59 & 0,58 & 0,72 & 0,74 & 0,61 & 1,04 & 0,57 & 0,3 & 0,45 & 0,84 & 0,3 \\
\hline LOI & 3,21 & 2,79 & 2,12 & 2,49 & 2,08 & 0,63 & 2,31 & 3,15 & 2,84 & 2,03 & 3,18 & 1,84 \\
\hline Soma & 100,18 & 99,99 & 100,02 & 100,08 & 100,21 & 100,21 & 100,01 & 100,07 & 100,05 & 100,07 & 100,02 & 100 \\
\hline $\mathrm{Cr}$ & 172 & 94 & 50 & 63 & 55 & 116 & 75 & 45 & 173 & 151 & 104 & 153 \\
\hline $\mathrm{Ni}$ & 123 & 39 & 17 & 6 & 8 & 27 & 47 & 41 & 153 & 122 & 57 & 155 \\
\hline $\mathrm{Cu}$ & 58 & 29 & 38 & 41 & 20 & 36 & 32 & 26 & 50 & 54 & 36 & 47 \\
\hline $\mathrm{Ba}$ & 415 & 1064 & 1437 & 1765 & 808 & 969 & 522 & 1002 & 729 & 464 & 777 & 293 \\
\hline $\mathrm{Rb}$ & 10 & 85 & 46 & 68 & 61 & 68 & 20 & 45 & 46 & 16 & 65 & 13 \\
\hline $\mathrm{Sr}$ & 474 & 511 & 482 & 249 & 143 & 252 & 350 & 539 & 490 & 492 & 241 & 583 \\
\hline $\mathrm{Zr}$ & 100 & 181 & 257 & 272 & 329 & 344 & 409 & 279 & 104 & 121 & 269 & 112 \\
\hline $\mathrm{Y}$ & 25 & 32 & 47 & 48 & 64 & 56 & 51 & 37 & 22 & 25 & 47 & 22 \\
\hline $\mathrm{Nb}$ & 7 & 23 & 17 & 26 & 53 & 19 & 25 & 21 & 13 & 11 & 22 & 9 \\
\hline $\mathrm{La}$ & 14,4 & 20,3 & 26,4 & 36 & 43,6 & 41,6 & 37,3 & 35,6 & 14,1 & 14,2 & 28 & 14,2 \\
\hline $\mathrm{Ce}$ & 31,3 & 48,4 & 63,3 & 73,3 & 94,7 & 94 & 97,2 & 71,5 & 35,6 & 33,3 & 66,2 & 34,5 \\
\hline $\mathrm{Nd}$ & 18,1 & 28,8 & 33,8 & 37,6 & 51,4 & 43,4 & 45,7 & 31,5 & 20,6 & 19,4 & 37,4 & 19,5 \\
\hline $\mathrm{Sm}$ & 3,97 & 5,9 & 8,67 & 8,46 & 11,1 & 9,57 & 11,3 & 8,3 & 6,1 & 4,61 & 8,91 & 4,36 \\
\hline $\mathrm{Eu}$ & 1,53 & 1,8 & 2,36 & 2,6 & 2,4 & 2,46 & 2,85 & 2,3 & 1,6 & 1,5 & 2,28 & 1,66 \\
\hline $\mathrm{Gd}$ & 4,38 & 5,9 & 7,86 & 8,79 & 11,0 & 10,5 & 10,2 & 7,8 & 5,2 & 4,66 & 8,07 & 4 \\
\hline Dy & 3,91 & 4,870 & 7,17 & 7,14 & 9,390 & 9,11 & 8,21 & 6,640 & 5,560 & 4,05 & 8,42 & 3,21 \\
\hline Er & 2,22 & 2,450 & 3,57 & 4,14 & 5,910 & 5,18 & 3,79 & 3,420 & 2,200 & 1,54 & 3,68 & 1,98 \\
\hline $\mathrm{Yb}$ & 2,04 & 2,050 & 2,84 & 2,84 & 4,080 & 3,16 & 2,71 & 2,300 & 1,900 & 1 & 3,19 & 1 \\
\hline $\mathrm{Lu}$ & 0,300 & 0,200 & 0,330 & 0,400 & 0,550 & 0,400 & 0,35 & 0,210 & 0,190 & 0,13 & 0,43 & 0,17 \\
\hline
\end{tabular}


de rotina do laboratório (Malagutti et al. 1988).

Nos diagramas de Harker (1909) (Figs. 3Aa H) as amostras da Suíte Básica Intrusiva Rio Branco (SBIRB) apresentam-se com litotipos variando de rochas básicas a intermediárias apresentando um intervalo mais amplo de 45 a $54 \% \mathrm{SiO}_{2}$, sendo observado o agrupamento destas rochas em relação a sílica os das rochas básicas com valores menores de $52 \% \mathrm{SiO}_{2}$ mais enriquecido em $\mathrm{MgO}$ e $\mathrm{CaO}$ e empobrecidos em álcalis e o agrupamento das rochas intermediárias com valores de sílica acima deste patamar mais rica em álcalis e empobrecida em $\mathrm{MgO}$ e
$\mathrm{CaO}$, demonstrando constituir em uma sequência magmática mais diferenciada que SBISC.

As amostras da Suíte Básica Intrusiva Salto do Céu (SBISC) apresentam valores mais concentrados de sílica normais das rochas básicas 45 a $48 \%$ de $\mathrm{SiO}_{2}$, mas apresentam litotipos com valores levemente inferiores a $45 \% \mathrm{SiO}_{2}$ e consequentemente valores mais elevados de $\mathrm{MgO}$ e $\mathrm{CaO}$ e deficiência em álcalis. Para a rochas ultrabásicas com valores inferiores a $45 \%$ $\mathrm{SiO}_{2}$, sugere-se que estas amostras possam resultar de processos cumuláticos por cristalização fracionada dos
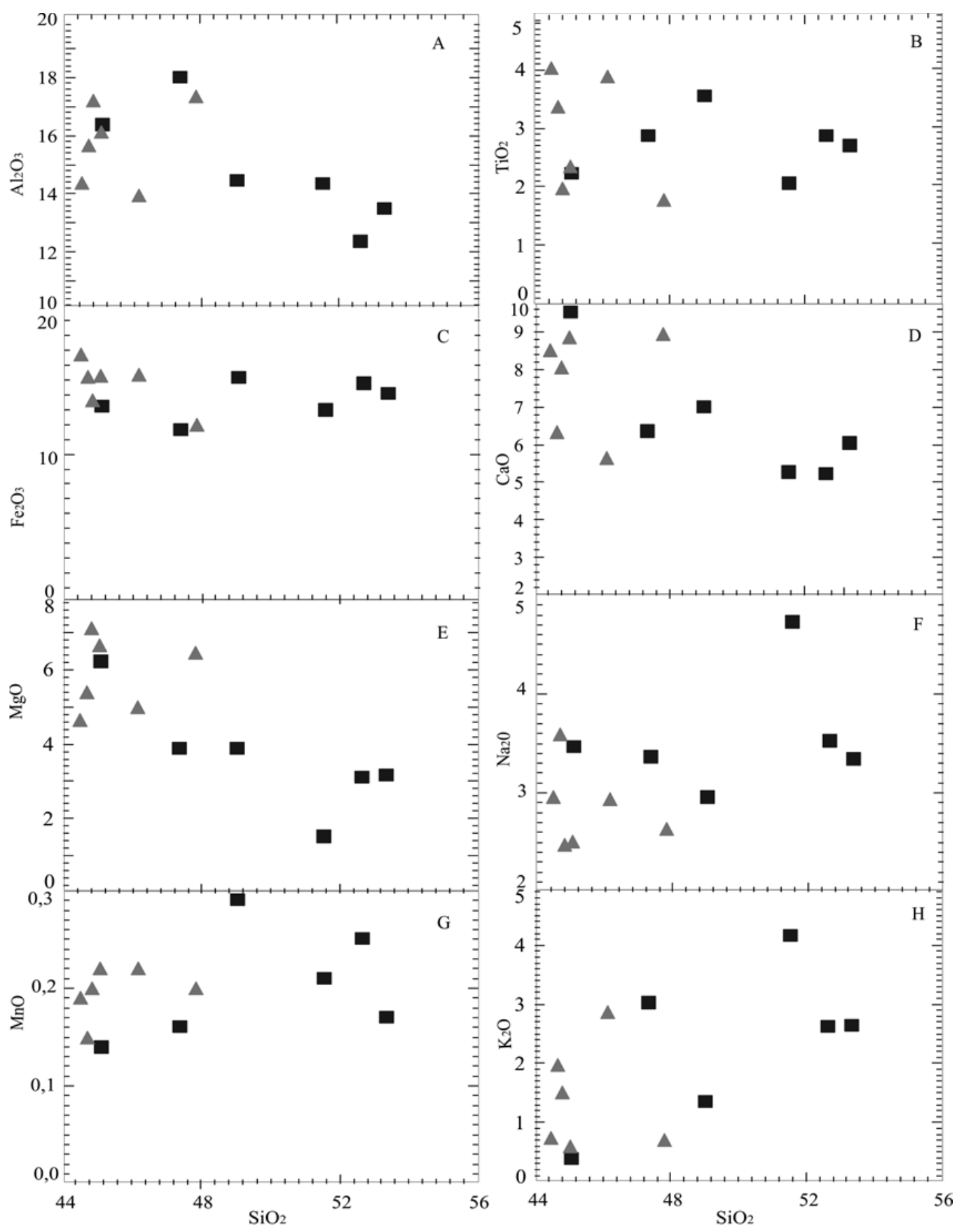

Figura 3 - Diagramas de variação de elementos maiores de Harker (1909) para a Suite Básica Intrusiva Rio Branco (ロ) e Suite Básica Intrusiva Salto do Céu (४). 
magmas básicos dos sills.

No diagrama de Middlesmost (1985) (Fig. 4A) apresentam-se nomenclaturas para as rochas da SBIRB posicionando-se em dois agrupamentos, os com valores levemente inferiores a $52 \% \mathrm{SiO}_{2}$ no campo dos álcali picrito e álcali olivina basalto e os com valores superiores a este patamar caracterizando rochas no campo traquibasaltos. As amostras analisadas da SBISC dominam nos termos dos álcalis picrito, álcalis olivina basalto e basanito.

Nos diagramas de Winchester \& Floyd (1977) (Figs. 4B e C) as amostras da SBIRB encontram-se definidas em dois agrupamentos na (Fig. 4B), a partir do limite de $52 \% \mathrm{SiO}_{2}$ das amostras, para as rochas com valores superiores dominam o campo do álcalis basalto e para as rochas com valores inferiores o campo do basalto subalcalino. As amostras da SBISC na (Fig. 4B) dispersam entre os campos basalto subalcalino e álcalis basalto.

O diagrama de Winchester \& Floyd (1977) da (Fig. 4C) as amostras da SBIRB também se encontram definidas em dois agrupamentos, as rochas mais empobrecidas em sílica no campo de sub-basalto alcalino a basalto alcalino e para as amostras mais enriquecidas em sílica no campo sub-basalto alcalino transicionando para andesitos, enquanto as amostra da SBISC encontram-se concentradas nos campos sub-basalto alcalino a basalto alcalino.

No diagrama de Irvane \& Baragar (1971) (Fig.
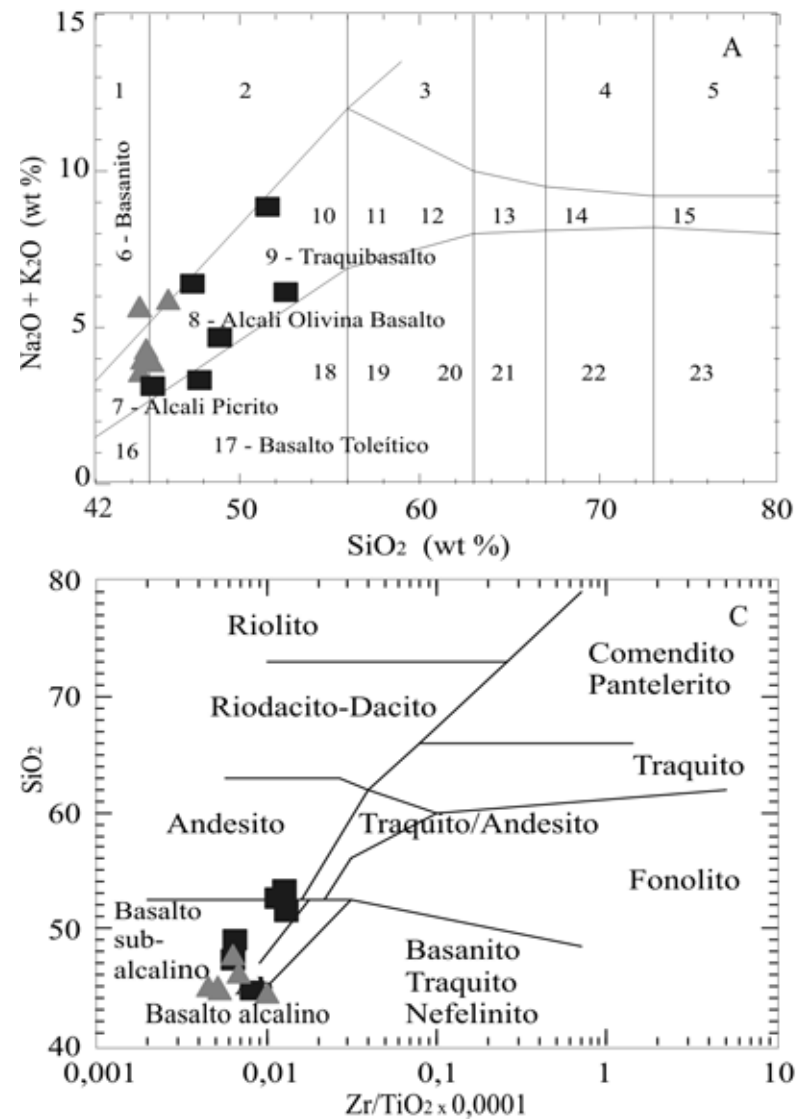

4D) as amostras das duas suítes situam-se dominantemente no campo das rochas de afinidades alcalinas, com amostras de ambas as fácies transicionando para sub-alcalinas, sendo que para as amostras da SBIRB apresentam uma maior tendência alcalina do que as amostras da SBISC.

No diagrama classificatório de Mullen (1983) (Fig. 5A), verifica-se que as amostras de ambas as suítes distribuem-se predominantemente no campo composicional dos basaltos alcalinos, sendo que algumas amostras da SBISC encontram-se na transição para basaltos toleíticos, mas dominantemente como basaltos alcalinos. No diagrama Jensen (1976) (Fig. 5B) as amostras das duas suítes distribuem-se no campo dos basaltos Fe-toleíticos.

No diagrama de Pearce \& Can (1973) (Fig. 5C) as amostras da SBIRB apresentam-se distribuídas nos dois agrupamentos característicos, para as amostras com maiores teores de sílica constituem no campo dos basaltos cálcio-alcalino (sub-alcalino) e o outro agrupamento no campo dos basaltos alcalinos de intraplaca, enquanto as amostras SBISC evidenciam o caráter de basaltos alcalinos de ambiente intraplaca.

No diagrama de Meschede (1986) (Fig. 5D) reforçam o caráter de basaltos sub-alcalinos transicionando para basaltos alcalinos de ambiente de intraplaca. No diagrama de Pearce \& Norry (1979) (Fig. 5E)
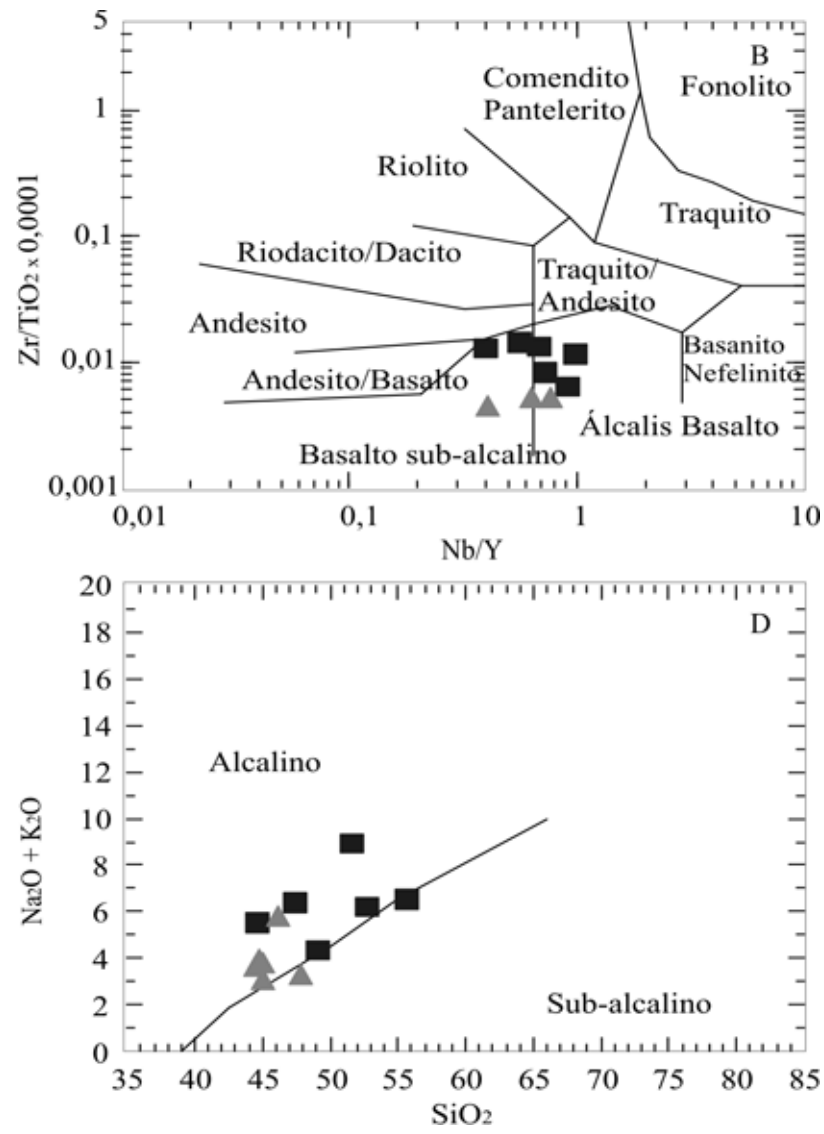

Figura 4 - Diagramas de classificação. A) Middlesmost (1985), B e C) Winchester \& Floyd (1977) e D) Irvane \& Baragar (1971) para a Suite Básica Intrusiva Rio Branco (ロ) e a Suite Básica Intrusiva Salto do Céu (४). 


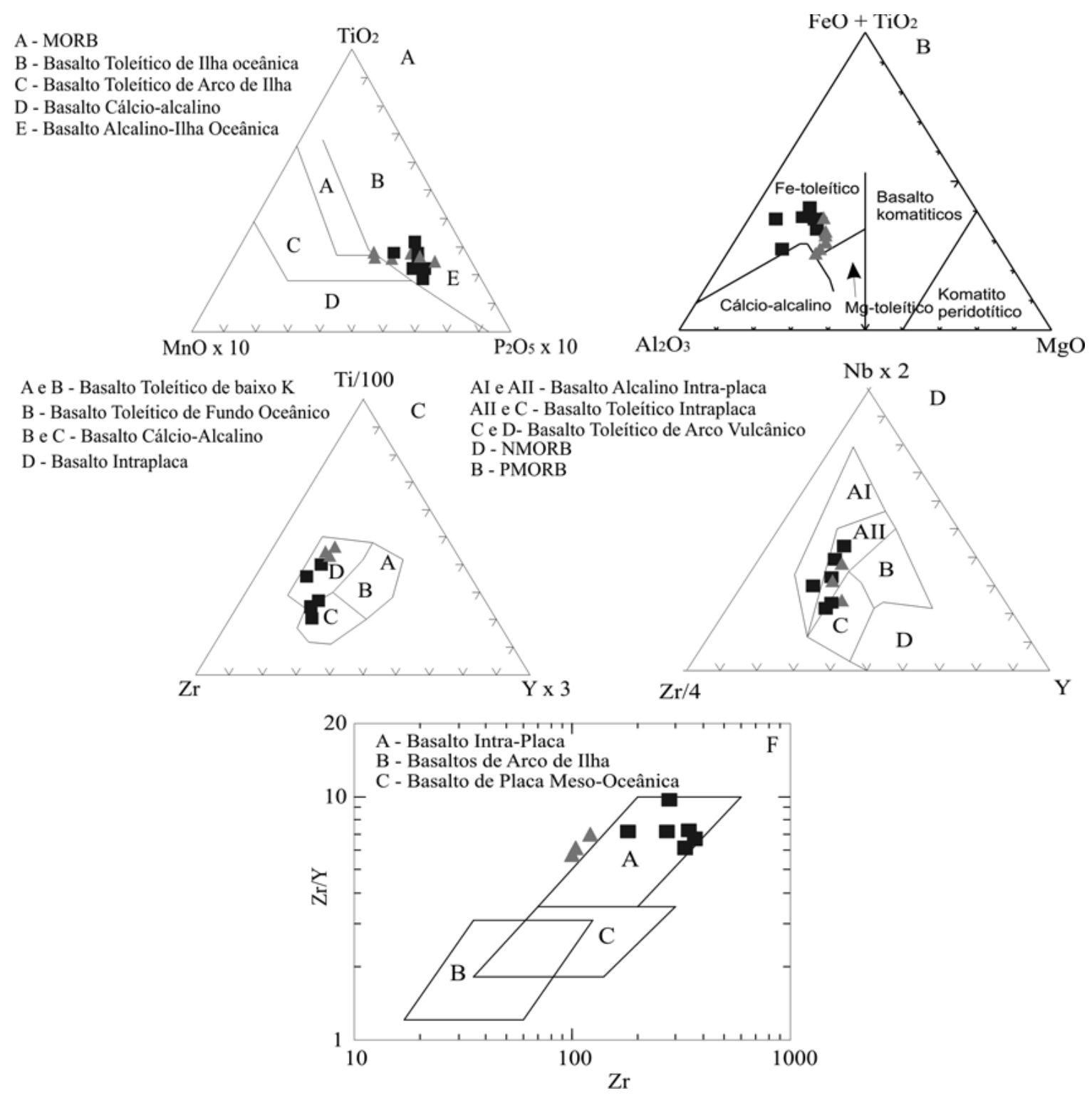

Figura 5 - Diagramas de classificação tectônica. A) Mullen (1983), B) Jensen (1976), C), Pearce \& Can (1973), D), Meschede (1986), E) Pearce \& Norry (1979), Suite Básica Intrusiva Rio Branco (ロ) e Suite Básica Intrusiva Salto do Céu (৯).

observa-se também para as amostras o domínio de basaltos de ambiente intraplaca.

Nos diagramas dos elementos traços normalizados pela (Sun \& McDonough 1989), apresentando para as duas suítes (Fig. 6A) e separadamente (Figs. 6C e E), apresentam os padrões de distribuição com um enriquecimento em $\mathrm{Ba}$, e empobrecimento em $\mathrm{Sr}$, podendo sugerir que no emplacement para as duas suítes não ocorreu contaminação crustal, visto que em nenhuma das relações $\mathrm{Rb} / \mathrm{Ba}$ das amostras os valores foram inferiores a 0,10 .

O comportamento geral dos elementos terras raras das suítes em relação ao padrão adotado para o condrito de Boynton (1984) apresentado para as duas suítes (Fig. 6B) evidencia padrões com uma disposição subparalela muito regular entre as suítes separadamente nas (Figs. 6D e F).
Observa-se para as amostras da SBIRB os dois agrupamentos já observados, o constituído pelas rochas básicas apresentando valores no geral empobrecidos em terras raras leves e pesadas e os das rochas intermediárias mais enriquecidas nas terras raras leves e pesadas, além de uma leve anomalia de Eu, resultado de uma maior diferenciação destas rochas, sugerindo a intensificação do processo de fracionamento do magma inicial, através da remoção dos plagioclásios e enriquecimento de feldspato potássio.

Para as rochas da SBISC destacam-se o maior empobrecimento em elementos terras raras pesadas e fracas anomalias de Eu, sugerindo uma maior participação do plagioclásio e de minerais acessórios no controle destes elementos.

Os valores dos elementos de terras raras da $\mathrm{Su}$ íte Básica Intrusiva Rio Branco (Fig. 6D), apresentam 

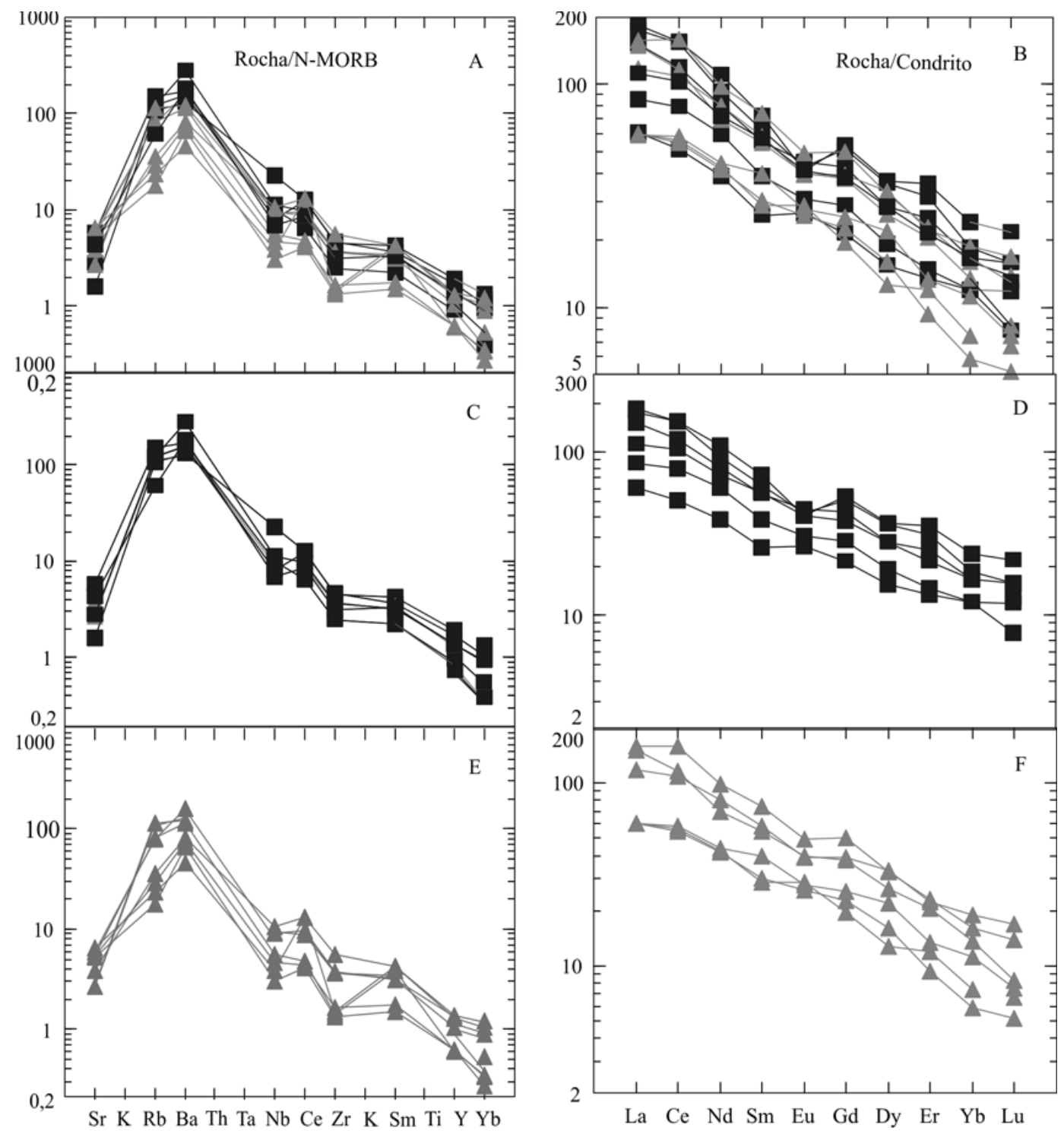

Figura 6 - Diagramas de elementos traços segundo Sun \& McDonough (1989), A) Total, C) Suite Básica Intrusiva Rio Branco (ロ) e E) Suite Básica Intrusiva Salto do Céu (४). Diagramas de elementos terras raras segundo Boynton (1984), B) Total, D) Suite Básica Intrusiva Rio Branco (ロ) e F) Suite Básica Intrusiva Salto do Céu (山).

um padrão de distribuição total mais enriquecido em [La/ $\mathrm{Yb}=7,2]_{\mathrm{N}}$, leves anomalias negativas e positivas de Eu, com $\left[\mathrm{Eu} / \mathrm{Eu}^{*}=0,86\right]_{\mathrm{N}}$ e um padrão de distribuição assimétrico e paralelo entre os litotipos, definido pelo valor de $\mathrm{Ce} / \mathrm{Sm}=3,16$ em relação ao valor de $\mathrm{Gd} / \mathrm{Yb}=0,24$. Observa-se o enriquecimento simétrico e contínuo de elementos terras raras e incremento de anomalias negativas de Eu na medida em que a fácies torna-se mais diferenciada.

Os valores dos elementos de terras raras da $\mathrm{Su}-$ íte Básica Intrusiva Salto do Céu (Fig. 6F), apresentam um padrão de distribuição dos elementos de terras raras total empobrecido em $[\mathrm{La} / \mathrm{Yb}=8,29]_{\mathrm{N}}$, fracas anomalias negativas de $\mathrm{Eu}$, com $[\mathrm{Eu} / \mathrm{Eu} *=0,92]_{\mathrm{N}}$ e um padrão com fraca assimetria definida pelo valor de $\mathrm{Ce} / \mathrm{Sm}=2,86 \mathrm{em}$ relação ao valor de $\mathrm{Gd} / \mathrm{Yb}=0,22$, demonstrando padrões assimétricos e paralelos.
GEOCRONOLOGIA Os resultados isotópicos foram obtidos a partir dos métodos Sm-Nd e U-Pb no Laboratório de Geocronologia da Universidade Federal de Brasília e serão associados aos dados isotópicos da literatura para as discussões. Os resultados obtidos, além dos dados da literatura encontram-se enumerados na tabela 3.

As análises isotópicas das amostras submetidas à determinação através do método $\mathrm{U} / \mathrm{Pb}$ conforme apresentadas na (Tab. 2) definem idade para a fácies monzogranitos a quartzo monzonitos vermelhos escuros rapakivis de $(1403 \pm 0.6 \mathrm{Ma})$ e para a fácies leucomonzogranitos vermelhos rapakivis idade de (1382 \pm $49 \mathrm{Ma})$, interpretadas como sendo as idades de cristalização dos magmas félsicos que deram origem a Suíte Ácida Intrusiva Rio Branco. As idades modelo $\mathrm{T}_{\mathrm{DM}}$, evidenciam um episódio de fracionamento do manto, em torno de $1,80-1,73 \mathrm{Ga}$. Os valores negativos de 
$\varepsilon_{\mathrm{Nd}(t)}$, de $-0,1$ a $-1,0$, sugerem a participação de material crustal na formação deste magma (Araújo 2008).

Esta idade encontra-se concordante com os dados U-Pb (Geraldes 2000), realizados nos granófiros da Suíte Intrusiva Rio Branco que indicaram idades de $1423 \pm 2 \mathrm{Ma}$.

Os resultados analíticos para a Suíte Básica Intrusiva Rio Branco (Tab. 2) indicam idade de cristalização das rochas básicas de $1469 \pm 31 \mathrm{Ma}$, as idades modelo $\mathrm{T}_{\mathrm{DM}}$, evidenciam um episódio de fracionamento do manto formado em torno de 1,86-1,2 Ga e os valores positivos dos litótipos estudados de $\varepsilon_{\mathrm{Nd}(t)}$, de $+1,9$ a $+8,9$, evidenciam que os protólitos intrusivos apresentam uma assinatura isotópica juvenil de manto derivado, e, portanto os valores de de $\varepsilon_{\mathrm{Nd}(t)}$ distintos sugerem uma evolução diferente desde a separação do manto, quando comparado às félsicas (Geraldes et al. 2004).

Segundo Araújo ( 2008) o magmatismo bimodal do batólito é plenamente evidenciado a partir de dois magmas, um de natureza básico gerado por derivação mantélica e outro, de composição ácido/intermediário formado por processos de fusão e participação de material crustal, e através de processo de diferenciação magmática, gerou-se as fácies de composições ácida/intermediária distintas, descartando o modelo de um complexo estratiforme diferenciado proposto por Leite et al. 1985.

Quanto aos processos de extensos de hibridismo definidos por Geraldes (2000), ressaltam-se processos desta natureza restritos e que as ocorrências de monzogranitos a quartzo-monzonitos rapakivi vermelhos com matriz mais escura, identificadas no interior do batólito, constituem em uma fácies inicial, menos diferenciada e de matriz mais rica em minerais máficos. Esta hipótese encontra-se reforçada pelas idades apresentadas das amostras analisadas das fácies da Suíte Ácida Intrusiva Rio Branco.

Os primeiros dados geocronológicos pelo método $\mathrm{Rb} / \mathrm{Sr}$ por Barros et al. (1982) de $1130 \pm 72 \mathrm{Ma}$ e Ruiz (1992) $1126 \pm 39 \mathrm{Ma}$ que consideram esta idade como o período de cristalização do magma rapakivi pertencente ao Esteniano, justificativa esta embasada pelas razões iniciais elevadas de ${ }^{87} \mathrm{Sr} r{ }^{86} \mathrm{Sr}, 0,708$ e 0,7165 , respectivamente, que assinalam uma natureza crustal ou evoluída para o magma parental, será admitida a proposta de Geraldes (2000) que ambas as idades representariam provavelmente o resultado da atividade hidrotermal que afetou as rochas da Suíte Rio Branco, já que estas rochas não se apresentam afetadas pelo metamorfismo regional.

Os resultados referentes à sistemática $\mathrm{U} / \mathrm{Pb}$ encontram-se na (Tab. 4) e na (Fig. 7) para as rochas da Suíte Básica Intrusiva Salto do Céu apresentam idade de $808 \pm 620$ Ma para cristalização do magma básico (Araújo 2008). As idades modelo $\mathrm{T}_{\mathrm{DM}}$, evidenciam um episódio de fracionamento do manto, em torno de 1,7 Ga. O valor positivo de $\varepsilon_{\mathrm{Nd}(t)}$, de $(+2,61)$, evidencia que os protólitos destas rochas apresentam uma assinatura isotópica típica de materiais derivados do manto.

Os resultados K-Ar apresentados na (Tab. 4) obtidos em plagioclásio dos diabásios e microgabros da Suíte Salto do Céu, indicam um episódio de resfriamento das soleiras máficas, entre 1015 Ma a 875 Ma.

Tabela 3 - Sintese do acervo de dados isotópicos para as rochas do Batólito Rapakivi Rio Branco e da Suite Básica Intrusiva Salto do Céu. Material datado: (RT) rocha total, (Pl) plagioclásio, (Zrn) zircão, (Tti) titanita.

\begin{tabular}{|c|c|c|c|c|c|c|c|c|c|}
\hline \multirow{2}{*}{\multicolumn{2}{|c|}{$\begin{array}{c}\text { Unidades } \\
\text { Litoestratigráficas }\end{array}$}} & \multirow[b]{2}{*}{ Referências } & \multirow{2}{*}{$\begin{array}{l}\mathrm{U}-\mathrm{Pb} \\
\text { Idade } \\
(\mathrm{Ma})\end{array}$} & \multicolumn{2}{|c|}{$\mathrm{Rb}-\mathrm{Sr}$} & \multicolumn{3}{|c|}{ Sm-Nd } & \multirow{3}{*}{$\begin{array}{c}\text { K-Ar } \\
\begin{array}{c}\text { Idade } \\
(\mathrm{Ma})\end{array} \\
\text { (P1) } 1006 \pm 16\end{array}$} \\
\hline & & & & \multirow[t]{2}{*}{$\begin{array}{l}\text { Idade } \\
(\mathrm{Ma})\end{array}$} & \multirow[t]{2}{*}{$\begin{array}{l}\mathrm{Sr}^{87} / \\
\mathrm{Sr}^{86} \\
\end{array}$} & \multirow[t]{2}{*}{$\mathrm{T}_{\mathrm{DM}}$} & \multirow[t]{2}{*}{$\varepsilon_{\mathrm{Nd}(0)}$} & \multirow[t]{2}{*}{$\varepsilon_{\mathrm{Nd}(\mathrm{t})}$} & \\
\hline \multirow{9}{*}{$\begin{array}{l}\text { Magmatismo } \\
\text { Ácido e Básico } \\
\text { Rio Branco }\end{array}$} & \multirow{2}{*}{ Rio Branco } & \multirow{2}{*}{$\begin{array}{l}\text { Hama (1976) in } \\
\text { Ruiz (2005) }\end{array}$} & & & & & & & \\
\hline & & & & & & & & & $(\mathrm{RT}) 1450 \pm 20$ \\
\hline & \multirow[b]{2}{*}{$\begin{array}{c}\text { Grupo } \\
\text { Rio Branco }\end{array}$} & $\begin{array}{l}\text { Barros et al. (1982) } \\
\text { (félsica) }\end{array}$ & & $\begin{array}{c}(\mathrm{RT}) \\
1130 \pm 72\end{array}$ & 0,708 & & & & \\
\hline & & $\begin{array}{l}\text { Barros et al. (1982) } \\
\text { (básica) }\end{array}$ & & & & & & & $\begin{array}{r}\text { (RT) } 875 \pm 21 \\
\text { (P1) } 878 \pm 10 \\
\text { (Pl) } 930 \pm 14 \\
\text { (P1) } 960 \pm 21\end{array}$ \\
\hline & \multirow{2}{*}{$\begin{array}{c}\text { Suíte } \\
\text { Intrusiva } \\
\text { Rio Branco }\end{array}$} & $\begin{array}{l}\text { Saes \& Leite (1993) } \\
\text { (félsica) in Ruiz (2005) }\end{array}$ & & $\begin{array}{c}(\mathrm{RT}) \\
1126 \pm 39\end{array}$ & 0,7165 & & & & \\
\hline & & $\begin{array}{l}\text { Saes \& Leite (1993) } \\
\text { (básica) in Ruiz (2005) }\end{array}$ & & & & & & & (Pl) $1015 \pm 17$ \\
\hline & \multirow{2}{*}{$\begin{array}{l}\text { Complexo } \\
\text { Rio Branco }\end{array}$} & $\begin{array}{c}\text { Geraldes et al. (2004) } \\
\text { (Granófiro) }\end{array}$ & $\begin{array}{c}(\mathrm{Zrn}) \\
1423 \pm 02\end{array}$ & & & $\begin{array}{l}1.8 \\
1.9\end{array}$ & $\begin{array}{l}-14.8 \\
-15.2 \\
\end{array}$ & $\begin{array}{l}-0.1 \\
-1.0 \\
\end{array}$ & \\
\hline & & $\begin{array}{l}\text { Geraldes et al. (2004) } \\
\text { (Gabro) }\end{array}$ & $\begin{array}{c}(\mathrm{Zrn}) \\
1469 \pm 31 \\
\end{array}$ & & & $\begin{array}{l}1.2 \\
1.8 \\
\end{array}$ & $\begin{array}{l}-8.3 \\
-10.0 \\
\end{array}$ & $\begin{array}{l}+8.9 \\
+1.9 \\
\end{array}$ & \\
\hline & $\begin{array}{c}\text { Batólito } \\
\text { Rapakivi } \\
\text { Rio Branco }\end{array}$ & $\begin{array}{c}\text { Araújo (2008) } \\
\text { (Suíte Ácida Intrusiva } \\
\text { Rio Branco) }\end{array}$ & $\begin{array}{c}(\mathrm{Zrn}) \\
1403 \pm 06\end{array}$ & & & 1,9 & $-16,3$ & $-1,7$ & \\
\hline $\begin{array}{l}\text { Magmatismo } \\
\text { Básico Salto do } \\
\text { Céu }\end{array}$ & & $\begin{array}{c}\text { Araújo (2008) } \\
\text { (Suíte Básica Intrusiva } \\
\text { Salto do Céu) }\end{array}$ & $\begin{array}{c}(\mathrm{Tti}) \\
808\end{array}$ & & & 1,7 & $-6,2$ & $+2,6$ & \\
\hline
\end{tabular}




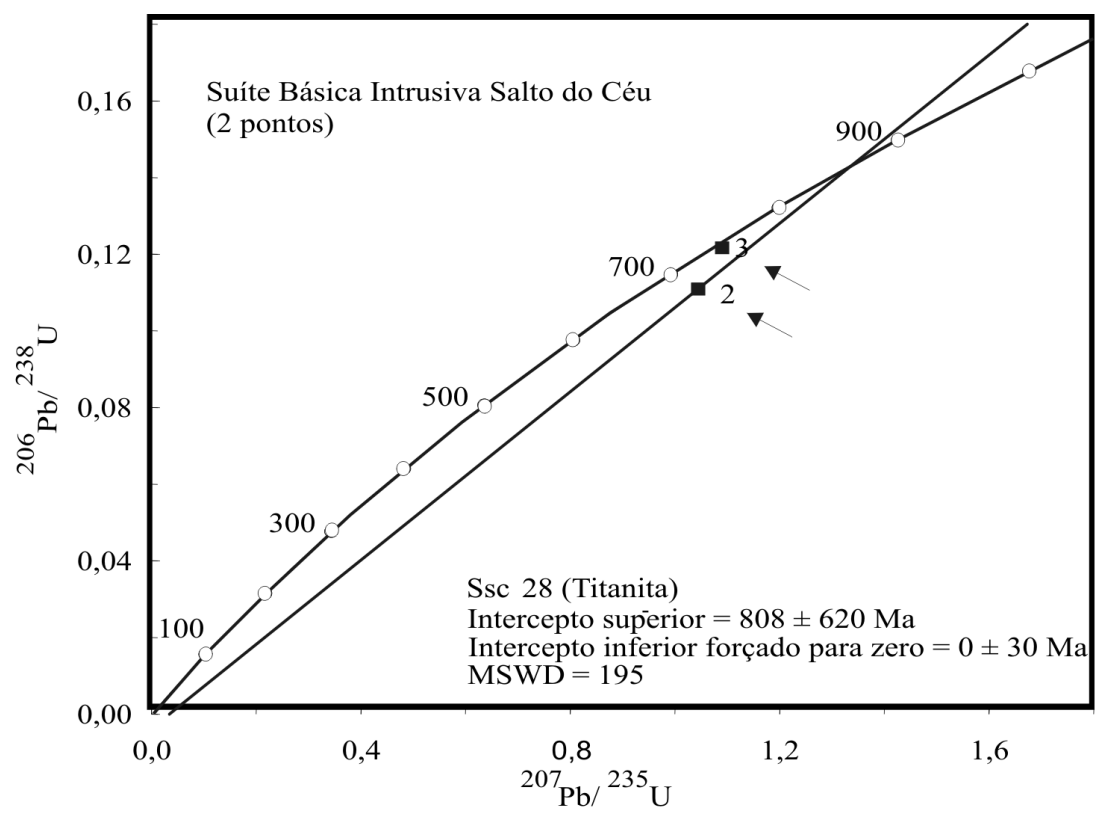

Figura 7 - Diagrama concórdia de amostra da Suite Básica Intrusiva Salto do Céu.

Tabela 4 - Resultados Sm-Nd e U/Pb para rochas da Suite Básica Intrusiva Salto do Céu.

\begin{tabular}{c|c|c|c|c|c|c|c|c|c|c|c}
\hline & $\mathrm{N}^{\circ}$. Campo & $\begin{array}{c}\mathrm{Sm} \\
(\mathrm{ppm})\end{array}$ & $\mathrm{Nd} \mathrm{ppm})$ & ${ }^{147} \mathrm{Sm} /$ & ${ }^{143} \mathrm{Nd} /$ & $€_{\mathrm{Nd}(0)}$ & $\mathrm{f}_{\mathrm{Sm} / \mathrm{Nd}}$ & $\begin{array}{c}\mathrm{T}_{\mathrm{DM}} \\
(\mathrm{Ga})\end{array}$ & $€_{(\mathrm{TDM})}$ & $\begin{array}{c}\mathrm{U} / \mathrm{Pb} \\
\mathrm{Ma})^{*}\end{array}$ & $€_{\mathrm{Nd}(\mathrm{T})}$ \\
\hline Salto do Céu & $\mathrm{Ssc} 28$ & 8,762 & 47,829 & 0,1107 & 0,511863 & $-6,25$ & $-0,44$ & 1,74 & 4,02 & 808,0 & $+2,61$ \\
\hline
\end{tabular}

Esses resultados geocronológicos posicionam esse evento magmático de natureza básica, como um registro geológico de um evento extensional, provavelmente relacionado aos mecanismos de colapso orogênico associado à evolução do cinturão Orogênico Sunsás-Aguapeí.

Esta idade colabora com as feições de campo de que estas rochas básicas tratam-se de um grande sills e localmente diques mais jovens, muitas vezes em contato direto com as rochas da Suíte Básica Intrusiva Rio Branco.

CONCLUSÕES Quanto à associação básica com ampla área de ocorrência na região de Rio Branco foi possível a identificação de dois eventos básicos dispostos lateralmente, mas independentes.

A mais antiga, encontra-se associada ao Batólito Rapakivi Rio Branco e é constituída pelas rochas básicas/ intermediárias denominadas de Suíte Intrusiva Básica Rio Branco composta por gabros a quartzo grabros e monzodioritos a quartzo dioritos apresentando uma distribuição descontínua e localizada nas bordas da Suíte Intrusiva Ácida Rio Branco de expressão areal dominante do batólito.

O magmatismo Rio Branco é constituído a partir

\section{Referências}

Araújo L.M.B. 2008. Evolução do magmatismo pós-cinemático do Domínio Cachoeirinha: Suites Intrusivas Santa de dois magmas distintos de composição básica e ácida e representa um evento magmático de transição entre os tipos I e A, pós-orogênico a anorogênico. O evento magmático de natureza básico/intermediário é gerado por derivação mantélica e é constituído por basaltos alcalinos gerado em ambiente intraplaca, apresentando idades de cristalização de 1469 Ma e o evento ácido/intermediário apresenta idade de $1403 \mathrm{Ma}$, sendo relacionados ao final do evento colisional da Orogenia Cachoeirinha.

O magmatismo da Suíte Básica Intrusiva Salto do Céu é composto por litotipos básicos hipoabissais mais jovens e de maior abrangência na região e são constituídos por diabásios e microgabros que se distribuem na forma de diques e de grandes sills concordantemente aos estratos do Grupo Aguapeí. São constituídos por basaltos alcalinos formados em ambiente intraplaca com idade de resfriamento/cristalização de $808 \mathrm{Ma}$ e caracterizam um evento extensional, provavelmente relacionado aos mecanismos de colapso orogênico na evolução do cinturão Orogênico Sunsás-Aguapeí.

Agradecimentos Este trabalho teve o apoio financeiro da FAPESP (proc. $n^{\circ}: 2004 / 00653-5$ ). 
ências Exatas, Universidade Estadual Paulista, 158p.

Araújo-Ruiz L.M.B., Ruiz A.S., Godoy A.M., Sousa M.Z.A. 2005. Soleiras máficas tonianas (Suíte Intrusiva Salto do Céu) no SW do Cráton Amazônico: regime extensional relacionado à Orogenia Sunsás?. In: SBG, Simp. CentroOeste, 9, Anais, p. 5.

Araújo-Ruiz L.M.B., Godoy A.M., Ruiz A.S., Souza M.Z.A., Montano L.F.M. 2007a. Geologia e geoquímica do Batólito Rapakivi Rio Branco, SW do Cráton Amazônico - MT. Geol. USP Sér. Cien., 7(1):57-72.

Araújo-Ruiz L.M.B., Godoy A.M., Ruiz A.S. 2007b. Soleiras Máficas Tonianas (Suíte Básica Intrusiva Salto do Céu) vs Diques Máficos Calymmiano (Suíte Básica Intrusiva Rio Branco), região de Rio Branco (MT), SW do Cráton Amazônico. In: SBGq, Congr. Bras. Geoq., 11, Anais, Cd-Room.

Barros A.M., Silva R.H., Cardoso O.R.F.A., Freire F.A., Souza Jr. J.J., Rivetti M., Luz D.S., Palmeira R.C.E., Tassinari C.C.G. 1982. Geologia. Folha SD. 21. Cuiabá. Rio de Janeiro, Ministério das Minas e Energia, Projeto Radambrasil, Levantamentos de Recursos Naturais, 26:25192.

Batchelor R.A., \& Bowden P. 1985. Petrogenetic interpretation of granitc rock series using multicationic parameters. Chemical Geology, 48:43-55.

Boynton W.V. 1984. Cosmochemistry of the rare-earth elements: meteorite studies. In: Henderson P. (ed.) RareEarth Elements Geochemistry. Amsterdam, Elsevier, p. 63-114.

Geraldes M.C. 2000. Geocronologia e geoquímica do plutonismo mesoproterozóico do SW do Estado de Mato Grosso (SW do Cráton Amazônico). Tese Doutoramento, IGc, Universidade de São Paulo, 193p.

Geraldes M.C., Bettencourt J.S., Texeira W., Matos J.B. 2004. Geochemistry and isotopic constraints on the origin of the mesoproterozoic Rio Branco 'anorogenic' plutonic suíte, SW of Amazônia craton, Brazil: high heat flow and crustal extension behind the Santa Helena arc? Journal of South American Earth Sciences, 17:195-208.

Harker A. 1909. The Natural History of Igneous Rocks. London, Methuen, 384p.

Irvine T.N. \& Baragar W.R.A. 1971. A guide to the chemical classification of the common volcanic rocks. Can. J. Earth Sci., 8:523-48.

Jensen L.S. 1976. A new cation plot for classifying subalkaline volcanic rocks. Ontario Division of Mines, Misc., Paper 66.

Leite J.A.D., Saes G., Weska R.K. 1985. A suíte Rio Branco e o Grupo Aguapeí nas serra de Rio Branco e Roncador. In: SBG, Simp. Centro-Oeste, 9, Anais, p. 247-255.

Malagutti M.I.A., Bahia Filho O., Moreno M.M.T., Nardy A.J.R. 1998. Determinação de elementos terras raras e ítrio em rochas silicáticas por ICP-AES com separação em resina trocadora de íons. Geochimica Brasiliensis, 12(1/2):75-80.

Meschede M. 1986. A method of discriminating between different types of mid-ocean ridge basalts and continental tholeiites with the Nb-Zr-Y diagram. Chem. Geol., 16:207-218.

Middlemost E.A.K. 1985. Magmas and Magmatic Rocks. An
Introduction to Igneous Petrology. London, Longman, $206 \mathrm{p}$.

Muller E.D. 1983. MnO/TiO2, P2O5: a minor element discriminant for basaltic rocks of oceanic environments and its implications for petrogenesis. Earth Planet. Sci. Lett., 62:53-62.

Oliva L.A. 1979. Ocorrências minerais na Folha Cuiabá (SD.21). Relatório de Viagem Goiânia, DNPM, 18p.

Pearce J.A. \& Cann J.R. 1973. Tectonic setting of basic volcanic rocks determined using trace element analyses. Earth and Plan. Sci. Lett., 19:290-300.

Pearce J.A. \& Norry M.J. 1979. Petrogenetic implications of $\mathrm{Ti}, \mathrm{Zr}, \mathrm{Y}$ and $\mathrm{Nb}$ variations in volcanic rocks. Contrib. Mineral. Petrol., 69:33-47.

Ruiz A.S. 1992. Contribuição a Geologia da Região do Distrito de Cachoeirinha - MT. Dissertação Mestrado, Instituto de Geociências, Universidade de São Paulo, 98p.

Ruiz A.S. 2005. Evolução Geológica do Sudoeste do Cráton Amazônico Região Limítrofe Brasil-Bolívia - Mato Grosso. Tese Doutorado, Instituto de Geociências e Ciências Exatas, Universidade Estadual Paulista, 247p.

RuizA.S., Matos J.B., Simões L.S.A., Araújo-Ruiz L.M.B.A., Sousa M.Z.A., Godoy A.M., Costa P.C.C., Fernandes C.J., Almeida H.L. 2005. Arcabouço litoestratigráfico e tectônico do Cráton Amazônico no SW de Mato Grosso: revisão e atualização. In: Viana R.R. \& Fernandes C.J. (eds.) I Coletânea Geológica de Mato Grosso. Cuiabá, UFMT, p. 15-32.

Saes G.S. 1999. Evolução tectônica e paleogeográfica do Aulacógeno Aguapeí (1.2 - 1.0Ga.) e dos terrenos do seu embasamento na porção sul do Cráton Amazônico. Tese Doutorado, IGc, Universidade de São Paulo, 135p.

Santos J.O.S., Hartmann L.A., Gaudette H.E., Groves D.I., Mcnaughton N.J., Fletcher I.R. 2000. A new understanding of the provinces of the Amazon Craton based on integration of field mapping and U-Pb and $\mathrm{Sm}-\mathrm{Nd}$ geochronology. Gondwana Research, 3:453-488.

Sun S.S. \& McDonough W.F. 1989. Chemical and isotopic systematics of oceanic basalts: implications for mantle composition and processes. In: Saunders A.D. \& Norry M.J. (eds.) Magmatism in ocean basins. Geol. Soc. London. Spec. Pub., 42:313-345.

Tassinari C.C.G. \& Macambira M.J.B. 1999. Geochronological provinces of the Amazonian Craton. Episodes, 38:174-182.

Vargas-Mattos G., Geraldes M.C., Shmitt R.S., Matos R., Teixeira W., Valencia V., Ruiz J. 2007. Geocronologia U-Pb de zircões detríticos do Grupo Aguapeí (Serra Ricardo Franco, Santa Bárbara e Saldo do Céu): Implicações na evolução geológica do SW do Cráton Amazônico. In: SBGq, Congr. Bras. Geoq., 11, Anais, CD-Room.

Winchester J.A. \& Floyd P.A. 1977. Geochemical discrimination of different magma series and their differentiation products using immobile elements. Chem. Geol., 20:325-343..

Manuscrito ID 11486

Submetido em 12 de junho de 2008 Aceito em 21 de junho de 2009 